\title{
UPPER CARBONIFEROUS-LOWER PERMIAN BUILDUPS OF THE CARNIC ALPS, AUSTRIA-ITALY
}

\author{
ELIAS SAMANKASSOU \\ Université de Fribourg, Département de Géosciences, Géologie et Paléontologie, Pérolles, CH-1700 Fribourg, Switzerland \\ e-mail:elias.samankassou@unifr.ch
}

\begin{abstract}
Aвstract: A variety of buildup types occur in the upper Paleozoic Auernig and Rattendorf Groups, Carnic Alps, at the present-day Austrian-Italian border, including coral, diverse algal (Anthracoporella, Archaeolithophyllum, Rectangulina, and phylloid green), bryozoan, brachiopod, and sponge buildups. Thin mounds and banks have a diverse fossil association (e.g., Archaeolithophyllum-bryozoanbrachiopod mounds) and occur in siliciclastic-dominated intervals, as do coral buildups. Some of the biodiverse thin mounds occur in strata that were deposited in cooler water. However, the thickest mounds are nearly monospecific (e.g., Anthracoporella mounds) and grew in carbonate-dominated, warm-water environments.

Most of the mounds considered in this paper, particularly algal mounds, grew in quiet-water environments below wave base but within the photic zone. Mound growth was variously stopped by siliciclastic input, e.g., auloporid coral mounds, sea-level rise, e.g., the drowning of Anthracoporella mounds of the Rattendorf Group, influence of cool water, e.g., algal mounds of the Auernig Group overlain by limestone of cool-water biotic association, or sea-level fall, e.g., phylloid algal mounds that were subsequently exposed subaerially. There is no indication of ecological succession during mound growth. Growth, dimensions, biotic association, and termination of mounds seem to have been controlled by extrinsic factors, mainly sea level and water temperature.

Phylloid algal mounds are similar to those described from other late Paleozoic settings. Auloporid coral buildups, and Rectangulina and Anthracoporella algal buildups, however, have not previously been reported from other regions, although these fossils are described from several localities outside the Carnic Alps.
\end{abstract}

\section{INTRODUCTION}

Carbonate mounds are common features in upper Paleozoic rocks (Auernig and Rattendorf Groups) in the Carnic Alps, (part of the Southern Alps at the Austrian-Italian border (Fig. 1). Mounds from distinct formations of the Auernig and Rattendorf Groups have been described previously, but a review of the overall buildups is lacking. Boeckelmann (1985) and Krainer (1995) reported algal mounds in the Meledis and Auernig forma- tions, respectively, from the Auernig Group. Flügel and Krainer (1992) reported coral mounds from the Meledis Formation, Auernig Group. Flügel (1987) described Anthracoporella algal mounds from the Lower Pseudoschwagerina Limestone, Rattendorf Group, and Samankassou (1998) pointed out the constructional mode of Anthracoporella in the Carnic Alps.

The present paper reviews different buildup types within the Auernig and Rattendorf Groups, including those in intervals from which mounds are reported for the first time (Fig. 2). For the

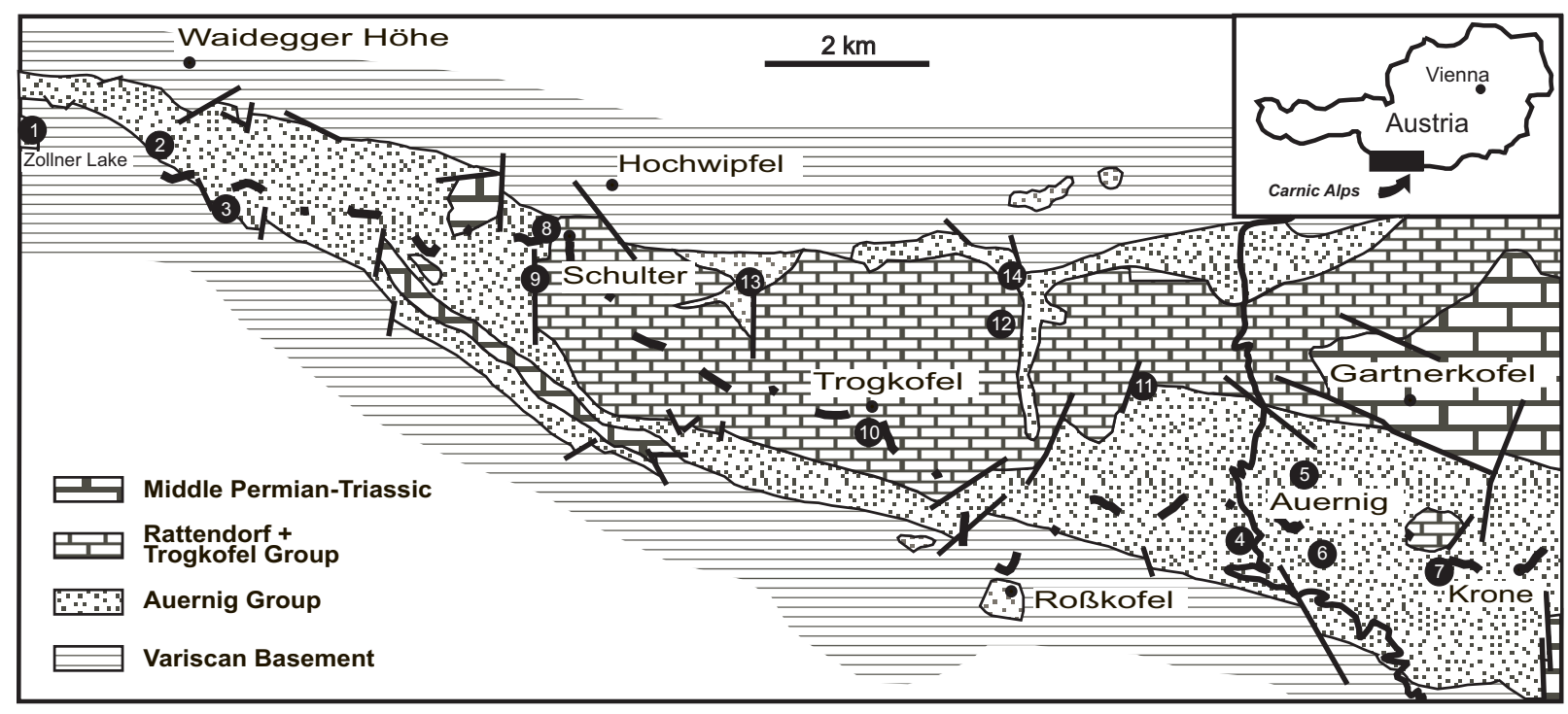

Fig. 1.-Location of the study area in the Carnic Alps, at the Austrian-Italian border. Numbers indicate locations of sections including buildups: 1-7 Auernig Group; 8-11 Lower Pseudoschwagerina Limestone; 12-13, Grenzland Formation; and 14, Upper Pseudoschwagerina Limestone. See Figure 2 for stratigraphy. 


\begin{tabular}{|c|c|c|c|}
\hline \multicolumn{2}{|c|}{ Stratigraphy } & \multicolumn{2}{|c|}{ Units of the study area } \\
\hline \multirow{3}{*}{ ن } & Artinskian & TROGKOFEL & \\
\hline & Sakmarian & \multirow{3}{*}{$\begin{array}{l}\text { RATTENDORF } \\
\text { GROUP }\end{array}$} & $\begin{array}{c}\text { Upper } \\
\text { Pseudoschwagerina } \\
\text { Limestone }\end{array}$ \\
\hline & Asselian & & $\begin{array}{l}\text { Grenzland } \\
\text { Formation }\end{array}$ \\
\hline \multirow{6}{*}{ 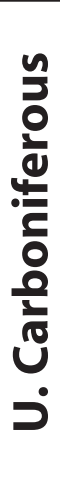 } & \multirow{4}{*}{ Gzhelian } & & $\begin{array}{c}\text { Lower } \\
\text { Pseudoschwagerina } \\
\text { Limestone }\end{array}$ \\
\hline & & \multirow{5}{*}{$\begin{array}{l}\text { AUERNIG } \\
\text { GROUP }\end{array}$} & Carnizza Formation \\
\hline & & & Auernig Formation \\
\hline & & & Corona Formation \\
\hline & \multirow{2}{*}{ Kasimovian } & & Pizzul Formation \\
\hline & & & Meledis Formation \\
\hline
\end{tabular}

FIG. 2.-Stratigraphic scheme of the Carnic Alps rocks.

Trogkofel Group, the reader is referred to the thorough description by Flügel (1981). The fossil associations of mounds studied allow paleoecological interpretation, particularly regarding the influence of sea-level fluctuations and the role of water temperature. Furthermore, comparisons are made to contemporaneous buildups in other areas. This enables recognition of the factors controlling Upper Carboniferous and Lower Permian buildups discussed below.

\section{GEOLOGICAL CONTEXT}

During Variscan orogenic movements (late Namurian to middle Westphalian), basins were formed in the areas of the Carnic Alps on the Austrian-Italian border (Fig. 1) and were filled with prodeltaic and shallow-marine sediments during the middle Carboniferous to Early Permian (Venturini, 1990). These rocks include the Upper Carboniferous to Lower Permian Auernig, Rattendorf, and Trogkofel groups (Fig. 2).

The Auernig and Rattendorf groups are composed of cyclic deposits. Quartz-rich conglomerates, cross-bedded sandstone, bioturbated siltstone with trace fossils and plant fossils, gray shale, and bedded and mounded limestone (Auernig Rythmus sensu Kahler, 1955; Krainer, 1992) characterize the Auernig Group.

The Rattendorf Group is subdivided into the Lower Pseudoschwagerina Limestone, the Grenzland Formation, and the Upper Pseudoschwagerina Limestone. The Lower Pseudoschwagerina Limestone has cyclic deposits similar to those of the Auernig Group, but carbonates are dominant (Homann, 1969; Samankassou, 1997). Siliciclastics dominate the Grenzland Formation, whereas the Upper Pseudoschwagerina
Limestone is again dominated by carbonates. The Trogkofel Group is composed mostly of massive reef carbonates (Flügel, 1980, 1981).

\section{MOUND TYPES}

\section{Auloporid Coral Mounds}

Auloporid coral mounds are known from two localities, Cima di Puartis and Rio Malinfier, in the Straninger Alm area (location 3, Fig. 1) and south of the Auernig area (location 4, Fig. 1) (Flügel and Krainer, 1992; Forke and Samankassou, 2000). The sequences studied are Kasimovian in age. The coral has been identified as Multithecopora syrinx (Etheridge 1900) by Flügel and Krainer (1992).

\section{Description.-}

Coral mounds are lens-like, with a flat base and a tabular or slightly domal top. They range from a few centimeters to $50 \mathrm{~cm}$ high and 80-90 cm long (Flügel and Krainer, 1992), and occur within sequences of silty shales (Fig. 3). The mound facies is an auloporid coral boundstone and packstone (Fig. 4). Corals are in growth position, with individual bodies very close to each other (Fig. 4A). The resulting framework pores are filled with micrite, peloids, marine cement, sponge spicules (?), wormtube like structures (similar to features known as Thartharella; cf. Wahlman, 1988; Samankassou, 2001), and shell fragments (Fig. 4). Other rare mound fossils include smaller foraminifers, fusulinids, and ostracodes. Flügel and Krainer (1992) have reported chaetetid sponges. The silty limestone facies below and above the mounds is similar to that of the matrix of the auloporid boundstones.

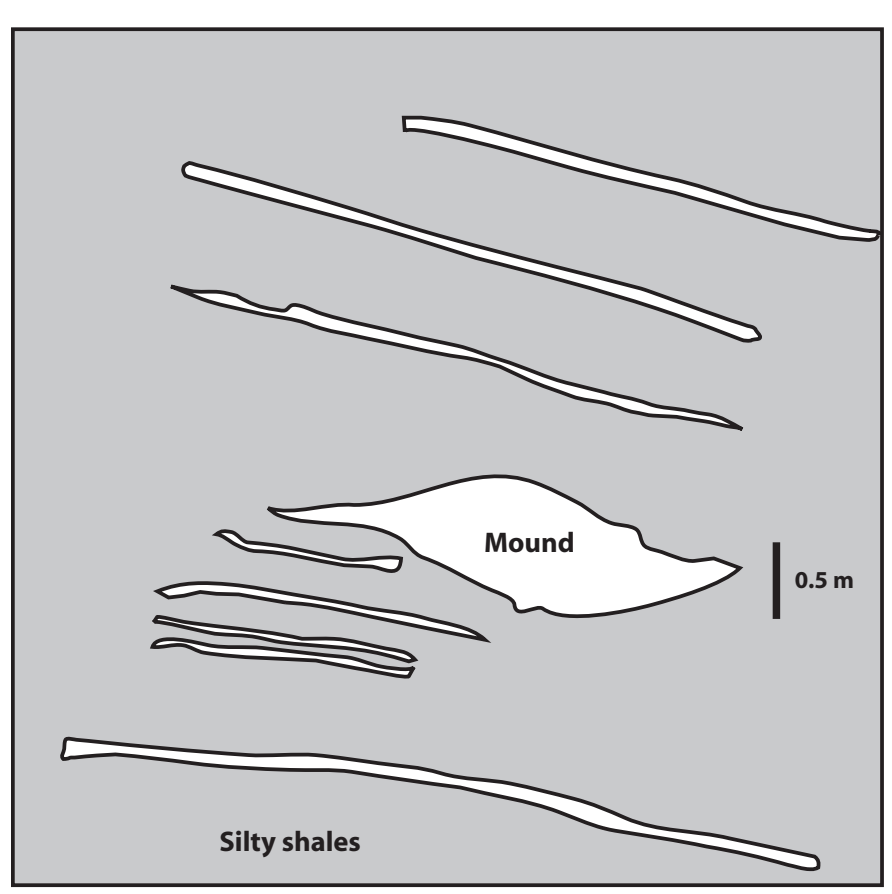

FIG. 3.-Sketch showing auloporid coral buildup in silty shales as seen in Cima Val di Puartis, locality 3 of Fig. 1. White discontinuous bands represent discontinuous marly limestone beds. 


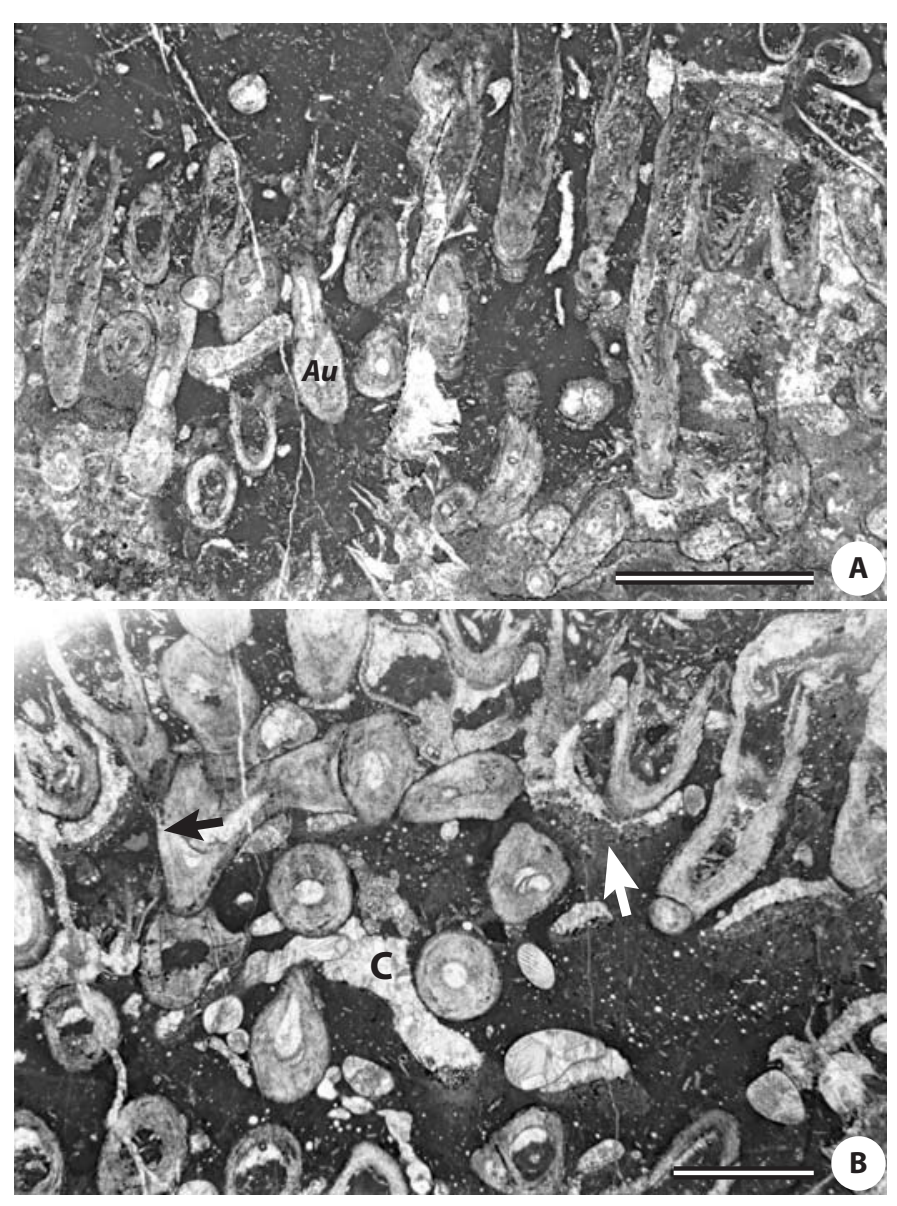

FIG. 4.-Auloporid coral boundstone. A) Corals $(A u)$, upright in growth position; framework pores filled with peloids, micritic and spar cement; and calcisiltite with sponge spicules (?), and small fossil fragments. Note that corallites are very closely spaced. B) Detail of framework, showing irregular framework cavities $(\mathrm{C})$ and the irregular contours of peloidal areas (white arrow). Agglutinated features similar to Thartharella occur (black arrow). A is oriented perpendicular to and, B parallel to, bedding plane. Scale bar is $5 \mathrm{~mm}$ long for both photomicrographs.

\section{Depositional Environment and Comparisons.-}

Unbroken fossils indicate limited transport prior to deposition. The muddy matrix of the auloporid mounds and the upright growth position of the corals indicate a low-energy depositional environment. Mounds grew during the early phase of sea-level highstand, when siliciclastic input was low (Flügel and Krainer, 1992). They did not form "classical", wave-resistant frameworks.

Encrusting corals, e.g., Syringopora and Caninia, are reported from other upper Carboniferous mounds (cf. West, 1988; Feldman and Maples, 1989; Tedesco and Wanless, 1989, 1995), but upright growth forms are of secondary importance in these buildups (Wilson, 1963; Fagerstrom, 1987). Generally these corals encrust, or are encrusted by, chaetetid sponges (see review in West, 1988). Thus, as concluded by Flügel and Krainer (1992), auloporid mounds are not common among upper Paleozoic buildups.

\section{Rugose Coral Biostromes}

Biostromes studied occur in the Grenzland Formation, Asselian in age, and crop out at locality 13 in Figure 1.

\section{Description.-}

Coral biostromes are a few centimeters thick and less than ten meters in lateral extent, and are dominated by solitary and massive colonial rugose corals (cerioid types) (Fig. 5A). Most fossils, particular solitary forms, are broken (Fig. 5B). Corals constitute approximately $30 \%$ of the whole rock and more than $60 \%$ of fossil volume. Fusulinids, crinoids, and Shamovella (formerly Tubiphytes; see Riding, 1993) are common. The matrix is typically peloidal clotted micrite (Fig. 5B). Pores are cement-filled.
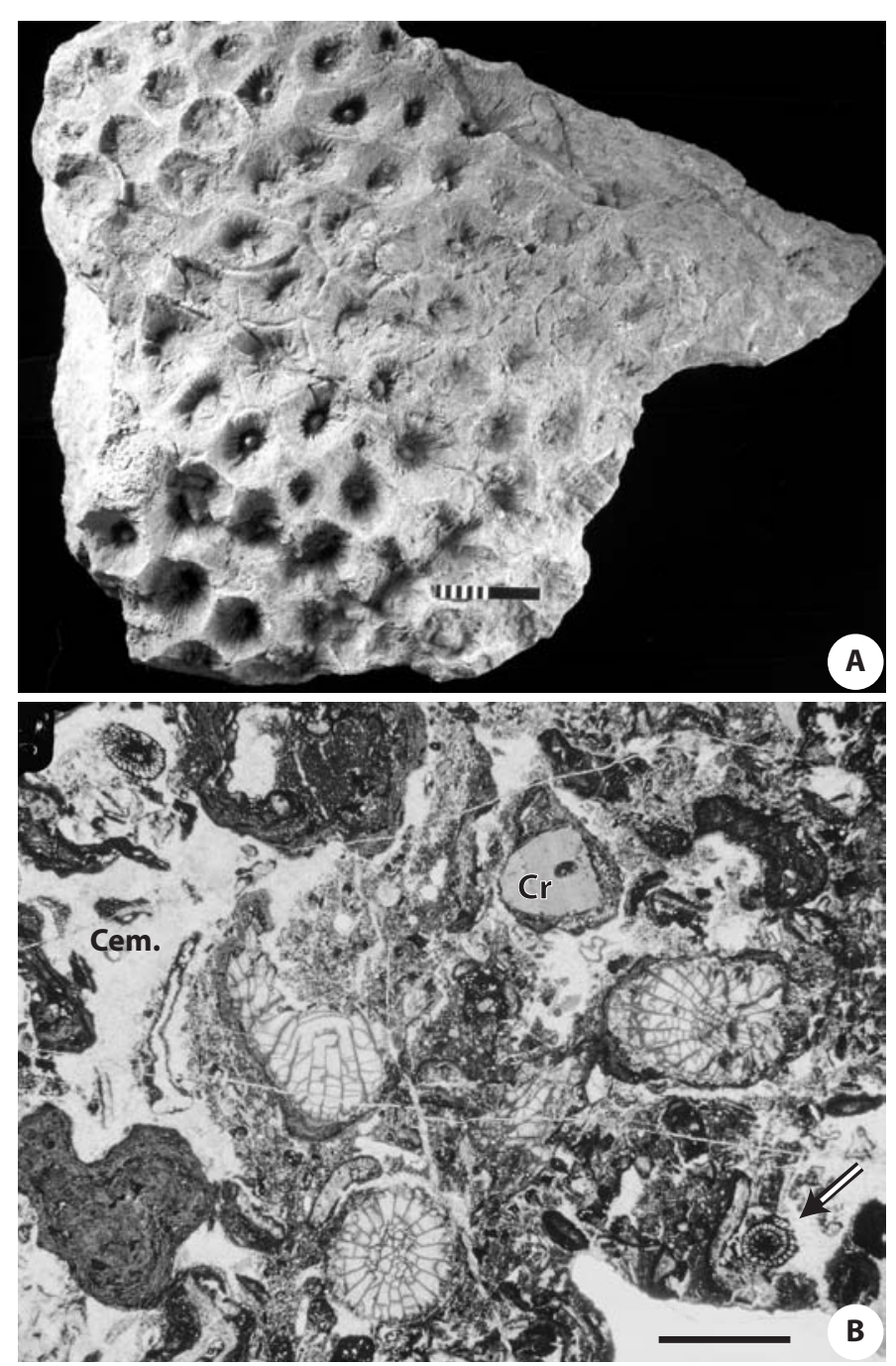

FIG. 5.-Coral biostromes. A) Coral colony. The small black-andwhite bars that make up the left half of the bar are in centimeters. B) Broken rugose corals in a bioclastic micritic matrix. Recognizable bioclasts other than coral fragments are fusulinids (arrow) and fragments of crinoid stems (Cr). Note the patchy distribution of cement-filled voids (white, Cem.). Scale bar is $10 \mathrm{~mm}$ long. 


\section{Depositional Environment and Comparisons.-}

The broken fossils indicate reworking prior to deposition, and the peloidal micritic matrix indicates that final deposition occurred in a quiet or moderate-energy environment.

As in other upper Paleozoic rocks, the contribution of corals to buildups in the Carnic Alps is minor. A rare occurrence is reported from Texas, U.S.A. (Young and Rush, 1956). As with the auloporid coral mounds described above, rugose coral biostromes occur in predominantly siliciclastic successions. The co-occurrence of solitary and colonial corals is not unusual in Carboniferous buildups (cf. Hill, 1939).

\section{Rectangulina Algal Mounds}

Mounds of the alga Rectangulina, up to $10 \mathrm{~m}$ long, occur in the Auernig (location 4, Fig. 1), and Zollner See (locations 1-3, Fig. 1) areas. The intervals involved belong to the lower part of the Auernig Group, early Kasimovian in age (Fig. 2).

\section{Description.-}

The thickest part of the Rectangulina buildups measured for this study was four meters (see Forke and Samankassou, 2000, for location and log of the section). The mound rock consists of indistinctly bedded limestone, which is an algal wackestone and packstone. Tube-like, straight, unsegmented thalli of the alga Rectangulina, commonly grouped in bundles (Fig. 6A, B), constitute more than $90 \%$ of the total biota. Other fossils include smaller foraminifers and the alga Beresella (Fig. 6B). The bioturbated matrix is peloidal, showing clotted grains, and constructional boundstone (e.g., upright elements, framework pores, and early cementation) is lacking.

\section{Depositional Environment and Comparisons.-}

The mud-rich facies and the abundance of fragile Rectangulina algal thalli indicate quiet-water conditions during mound growth. No erect growth forms occur, nor was there significant


FIG. 6.-Rectangulina packstone. A) Tube-like thalli are the dominant allochems (arrow, R). The peloidal matrix shows partly clotted structures (middle) and includes rare smaller foraminifers (For). B) Beresella (arrows) is the most common associated fossil. Black and white arrows at the respective corners indicate stratigraphic top. Scale bar is $2 \mathrm{~mm}$ long. 
syndepositional relief. Thus, the growth model is mechanical accumulation rather than a constructional (biogenic) one, according to Samankassou and West $(2000,2002$.).

The alga is generally rare and seems commonly associated with a bioturbated, peloidal facies (Mamet et al., 1987; Warnke, 1997). Rectangulina is reported from other localities, e.g., the Tethys and the Canadian Arctic (Mamet, 1991). Nevertheless, buildups of Rectangulina have not previously been reported outside the Carnic Alps. Even in the Carnic Alps, it is confined to a unique interval (Lower Kasimovian; Forke and Samankassou, 2000).

\section{Anthracoporella-Archaeolithophyllum Algal Mounds}

Mounds of the dasyclad alga Anthracoporella and the red alga Archaeolithophyllum crop out in the Auernig and Krone area (localities 5-7, Fig. 1) and are latest Kasimovian and Gzhelian in age.

\section{Description.-}

Mounds are three to eight meters thick (e.g., Krone, locality 7 in Fig. 1), ten of meters long, and commonly massive (Fig. 7). Commonly they are complex structures consisting of several smaller bodies (mini-mounds; Wilson, 1972; Samankassou, 1997). Irregular, discontinuous surfaces are common (Fig. 7A). The mound is boundstone, with a volumetrically important peloidal matrix (Figs. 7B, 8). The two algae rarely occur together; areas dominated by the dasyclad alga Anthracoporella spectabilis Pia 1920 generally lack the red alga Archaeolithophyllum missouriense Johnson 1956 and vice versa. Anthracoporella is commonly upright in growth position (Fig. 7B). Archaeolithophyllum, however, builds undulating, irregular crusts (Fig. 8A, B). The latter generally occurs in the basal part and at the top of the mounded interval. Other mound fossils include Shamovella (Fig. 8A, B), smaller foraminifers (Tuberitina, Palaeotextularia, Tetraxis), fusulinids, and, rarely, the alga Epimastopora, gastropods, and ostracodes.

\section{Depositional Environment and Comparisons.-}

The delicate framework and the muddy matrix suggest quietwater conditions. The abundant dasyclad alga Anthracoporella required a well-lit depositional environment. Thus, the mounds grew below (fair-weather) wave base, within the photic zone (Samankassou, 1998).

Archaeolithophyllum is an important mound builder in upper Carboniferous rocks, particularly in the Midcontinent of the U.S.A. (Laporte, 1962; Konishi and Wray, 1961; Wray, 1964, 1977; Heckel and Cocke, 1969; Welch, 1977; Toomey and Babcock, 1983; West, 1988; Samankassou and West, this volume). Wray (1964) and Linehan and Sutterlin (1986) reported boundstone texture similar to that described in the present paper. Anthracoporella mounds, however, have been reported only from the Carnic Alps. The co-occurrence of these two algae in mounds is unique to the Auernig Group and to the Carnic Alps.

\section{Phylloid Green Algal Mounds}

Phylloid green algal mounds, widespread in the Carnic Alps, occur in most of studied sections, ranging from Kasimovian to Sakmarian in age.

\section{Description.-}

Some phylloid algal buildups in the Auernig Group occur above or below Anthracoporella mounds (e.g., in the Corona Formation). The relief of these buildups is usually minor; small biostromes and banks a few decimeters thick and ten of meters long are the common structures (Fig. 9). Algal wackestone, boundstone, and, rarely, packstone are the dominant microfacies. Algal thalli constitute 80-90\% of the fossil content (Figs. 9, 10). Most accessory fossils are encrusting forms: the smaller foraminifers Tuberitina and Calcitornella, the red alga Ungdarella, Shamovella, worm tubes, and, rarely, fenestellid bryozoans (Samankassou, 1997). The heterogeneous matrix includes carbonate mud and irregularly shaped peloid- and cement-domi-
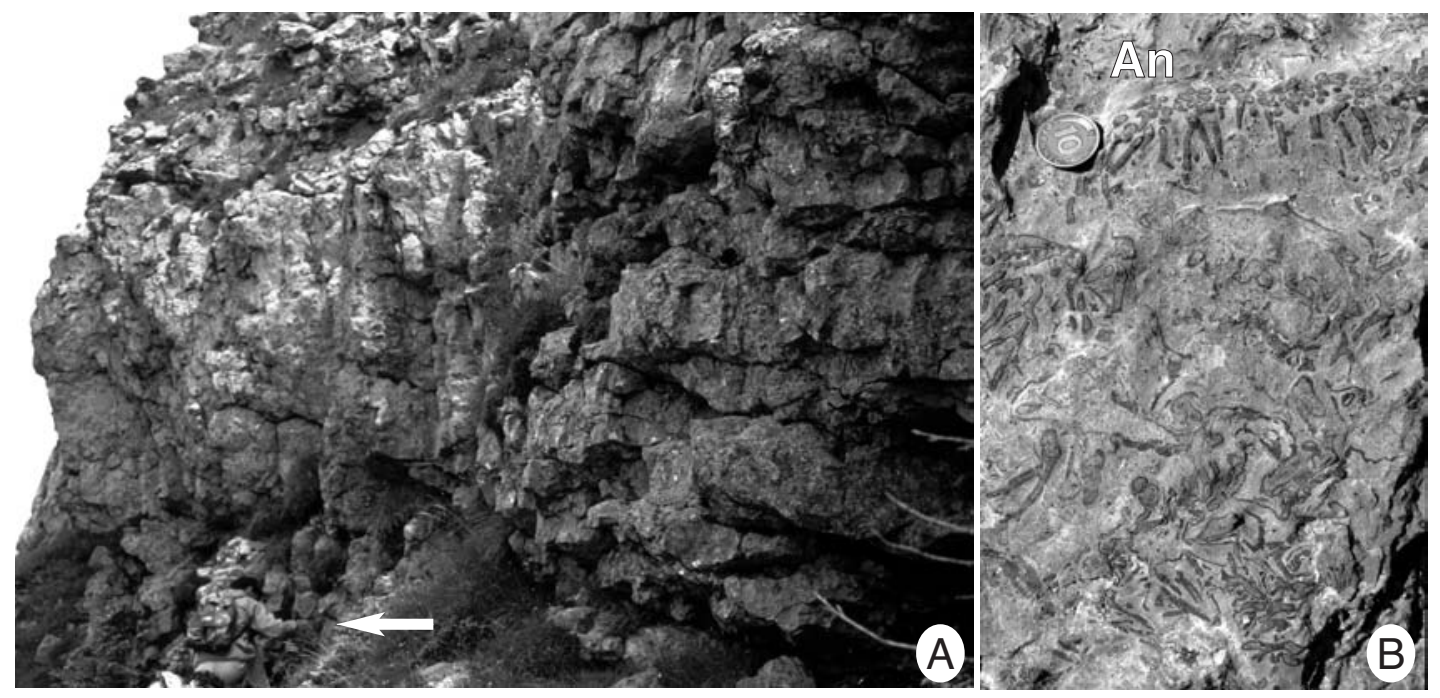

FIG. 7.-Anthracoporella-Archaeolithophyllum mounds. A) Massive part (left) passing into crudely bedded part (right) of mound. Mound is approximately seven meters thick (arrow showing person for scale) and extends for several tens of meters laterally. B) Anthracoporella (An) is commonly upright in growth position and usually forms small framework patches. Coin for scale is ca. 20 $\mathrm{mm}$ in diameter. 

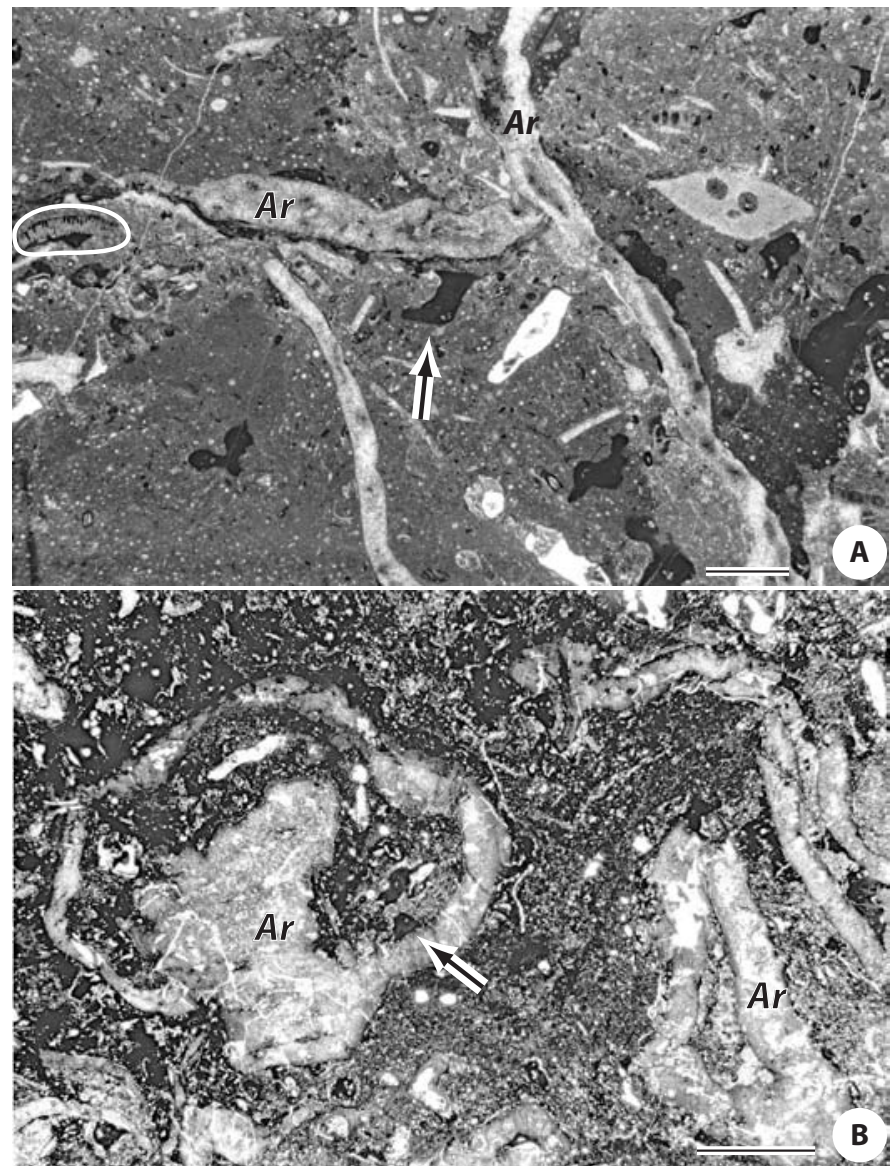

FIG. 8.-A, B) Archaeolithophyllum boundstone. Normally one of the two algae Archaeolithophyllum or Anthracoporella dominates, as does Archaeolithophyllum missouriense (Ar) in these figures. Only a fragment of Anthracoporella (8A, encircled) can be recognized. Note undulating forms and bifurcation of Archaeolithophyllum thalli (Wray, 1964) and the common encrusting Shamovella (arrows). Framework voids are filled mostly by peloidal sediment containing sponge spicules. Bar scale is $2 \mathrm{~mm}$ long.

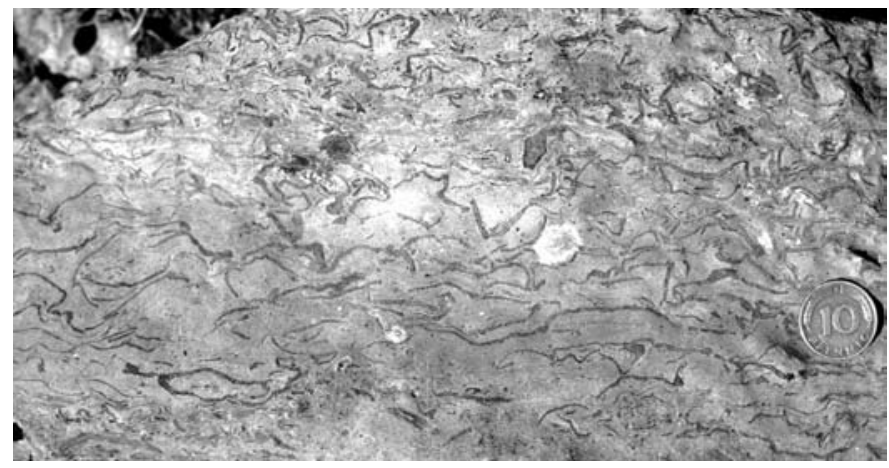

FIG. 9.-Phylloid algal mounds. Accumulation of leaf-like algal thalli. The very large thalli within a micritic matrix cannot be transported far prior to deposition. Coin for scale is ca. $20 \mathrm{~mm}$ in diameter.
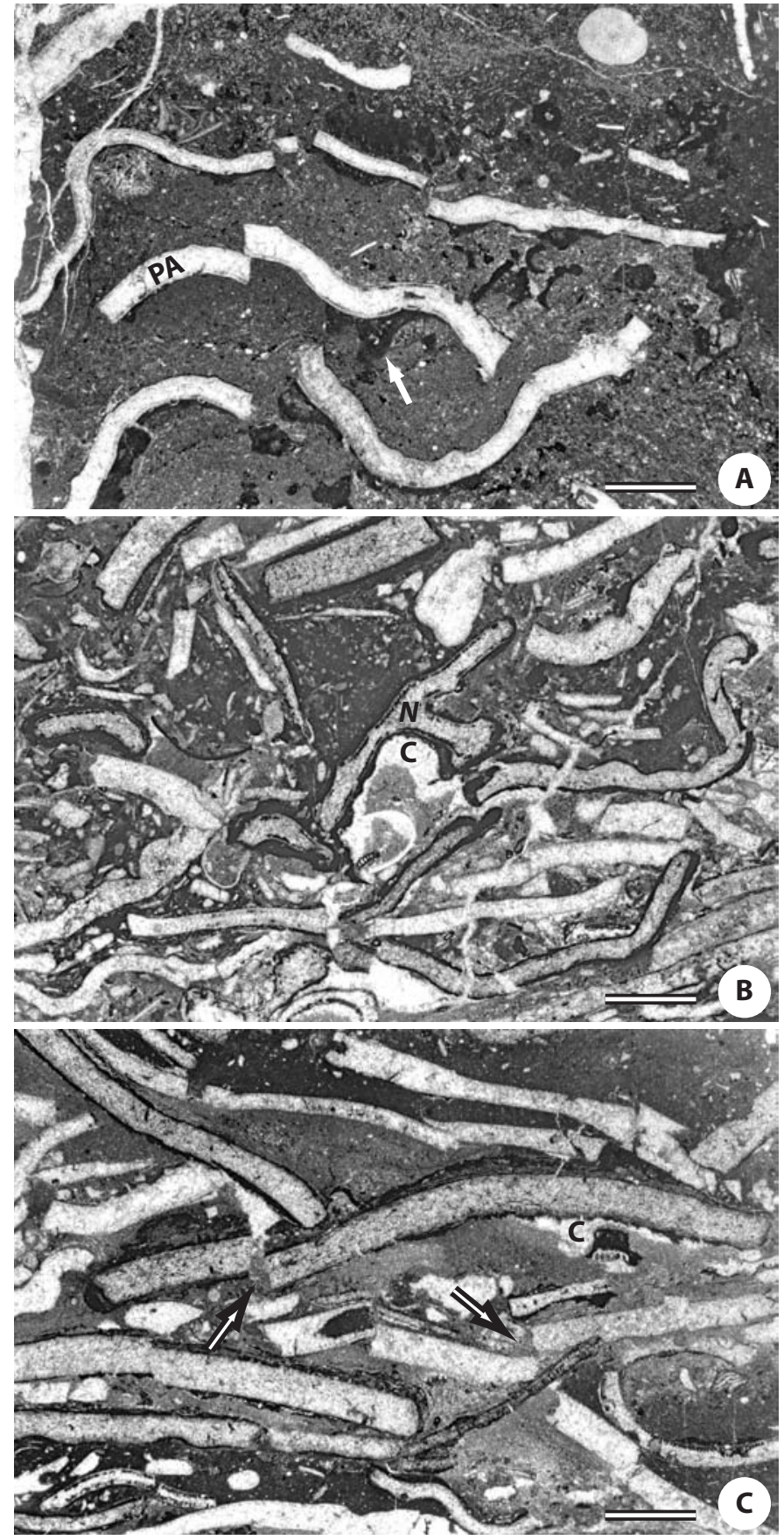

FIG. 10.-Phylloid algal boundstone. A) In situ brecciated, irregularly encrusted phylloid algal thalli (PA) in a peloidal micrite matrix with various bioclasts. Shamovella encrusts most of thalli (arrow). Scale bar is $2 \mathrm{~mm}$ long. B) Algal thalli (here Neoanchicodium $\mathrm{N}$ ) are obviously brecciated in situ. The matrix is micritic, peloidal, and contains diverse smaller bioclasts (cf. Wray, 1964; Samankassou and West, 2002). Scale bar is $5 \mathrm{~mm}$ long. C) Framework cavities (C) are filled with marine cement. Note the irregular contours of peloidal areas in cavities (C). The rarely identifiable thalli are of Eugonophyllum and Neoanchicodium. Collapse brecciation is indicated by thalli fragments that are slightly offset (arrows). Cement-filled cavities are more common than in Part A. Scale bar is $5 \mathrm{~mm}$ long. 
nated areas. Micritic cements are common. Mounds are capped by reddish, brecciated horizons and numerous fractures (Flügel et al., 1997).

\section{Depositional Environment and Comparisons.-}

Phylloid green algal thalli seem to have been brecciated in situ, as indicated by the arrangement of broken thalli (Fig. 10). Because thalli have not been transported and occur in a muddy facies, lowenergy conditions are inferred (Welch, 1977; Frost, 1975). No constructional features, such as the upright, cup-shaped growth forms described from the Midcontinent, U.S.A. (Samankassou and West, 2000, 2002, and this volume), occur in the Carnic Alps. The enclosed pores and broken algal thallus fragments that fit together indicate very little or no transportation and reworking prior to deposition. Biodiversity was relatively low, as is common in algal banks (Laporte, 1962; Heckel and Cocke, 1969; Heckel, 1974; Wilson, 1975; Toomey, 1976, 1991; Frost, 1975). These banks appear to have formed in very shallow, well-lit environments. Mound growth was terminated by subaerial exposure, as evidenced by fractured surfaces and reddish horizons capping mounds and including karst breccia.

Accumulation of phylloid algal thalli, growth of algal banks into shallower environments (shoals, capping facies; Wilson,
1975), and subsequent subaerial exposure are common patterns in upper Paleozoic phylloid algal facies (Pray and Wray, 1963; Wilson, 1975; Wray, 1977; Toomey et al., 1977; Toomey and Babcock, 1983; Dawson and Carozzi, 1986; among many others). The phylloid algal mounds studied, capped by horizons recording subaerial exposure, however, lack shallowing-upward trends.

\section{Archaeolithophyllum-Bryozoan-Brachiopod Mounds}

Archaeolithophyllum-bryozoan-brachiopod buildups commonly occur in the Pizzul and Auernig formations in localities 5 and 6 (Fig. 1) and are Kasimovian and Gzhelian in age.

\section{Description.-}

Archaeolithophyllum-bryozoan-brachiopod buildups are small, only a few decimeters thick, with massive to irregular bedding. Boundstone is the characteristic microfacies, with the red alga Archaeolithophyllum missouriense, fenestellid bryozoans, and ornament-rich brachiopods the main mound-building fossils (Fig. 11). Archaeolithophyllum encloses large cavities, up to $5 \mathrm{~mm}$ in size (Fig.11A). Bryozoans, Shamovella, and brachiopods encrust or are attached to the large, undulatory thalli of Archaeolithophyllum missouriense (Fig. 11B, C).
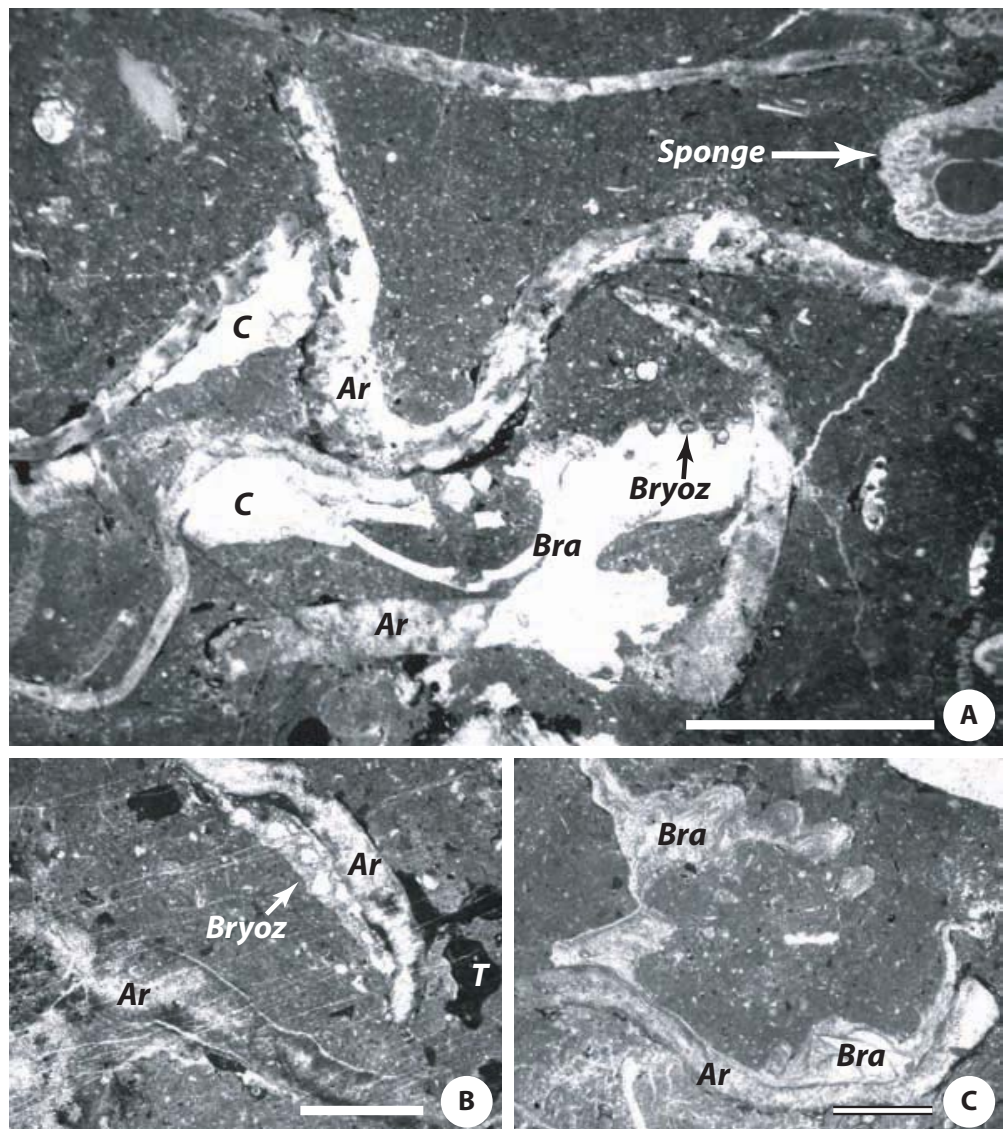

FIG. 11.-A-C) Archaeolithophyllum-bryozoan-brachiopod boundstone. Large, unbroken undulatory thallus of Archaeolithophyllum missouriense ( $A r$ in A-C) enclosing cavities (C), encrusting bryozoans (Bryoz in A, B), Shamovella (T in B), and ornament-rich brachiopods ( $\mathrm{Bra}$ in $\mathrm{C}$ ) are the main constituents. Fragment of bryozoans are common in the matrix, along with foraminifers, sponge spicules, and Shamovella. The fossil associations are very similar to those of the Midcontinent, U.S.A. (Wray, 1964, and subsequent workers). All figures are oriented perpendicular to bedding plane. Scale bar is $5 \mathrm{~mm}$ long for A and $2.5 \mathrm{~mm}$ for B and C. 
Additional fossils include the smaller foraminifers Palaeotextularia, Tuberitina, and Hemigordius, ostracodes, Shamovella, sponge spicules, and the problematic algae Efluegelia and Ungdarella, and rare calcareous sponges (Fig. 11A). The overall biodiversity is high. A peloidal matrix is characteristic, and cement fills interparticle pores (Fig. 11A).

\section{Depositional Environment and Comparisons.-}

The delicate, evident framebuilding and the micritic matrix of Archaeolithophyllum-bryozoan-brachiopod mounds indicatelowenergy conditions during deposition. Biodiversity is high, and in this respect Archaeolithophyllum-bryozoan-brachiopod mounds differ from other mounds of the Auernig Group and other mounds dominated by phylloid green algal species (see above).

Mound growth forms are very similar to those reported from the U.S. Midcontinent, as is the fossil association (Wray, 1964; Frost, 1975; Welch, 1977; among others). Samankassou and West (this volume) reported a higher biodiversity in red(Archaeolithophyllum)-algal-dominated mounds than that in greenalgal-dominated mounds from eastern Kansas, U.S.A. According to these authors, this may be related to difference in algal growth forms.
Rocks above the Archaeolithophyllum-bryozoan-brachiopod mounds have been interpreted as cool-water carbonates (Samankassou, 2002). Thus, the uncommon fossil association may be explained by temperature. Sequences that presumably have been influenced by cool-water currents are limited to specific intervals within the Auernig Group, and this may explain why buildups of this kind are confined to the Auernig Group (Samankassou, 2002).

\section{Anthracoporella Mounds}

Mounds of the dasyclad alga Anthracoporella, widespread in the Carnic Alps, occur in localities 5-7 and 8-11 (Fig. 1), dominantly in the Auernig Group and the Lower Pseudoschwagerina Limestone.

\section{Description.-}

The thickest mounds of the stratigraphic sections studied, up to 22 meters, occur in the Lower Pseudoschwagerina Limestone (Fig. 12A). Anthracoporella built delicate frameworks (Samankassou, 1998) as indicated by dense, commonly erect and unbroken thalli (Figs. 12B, 13) and cavities between algal

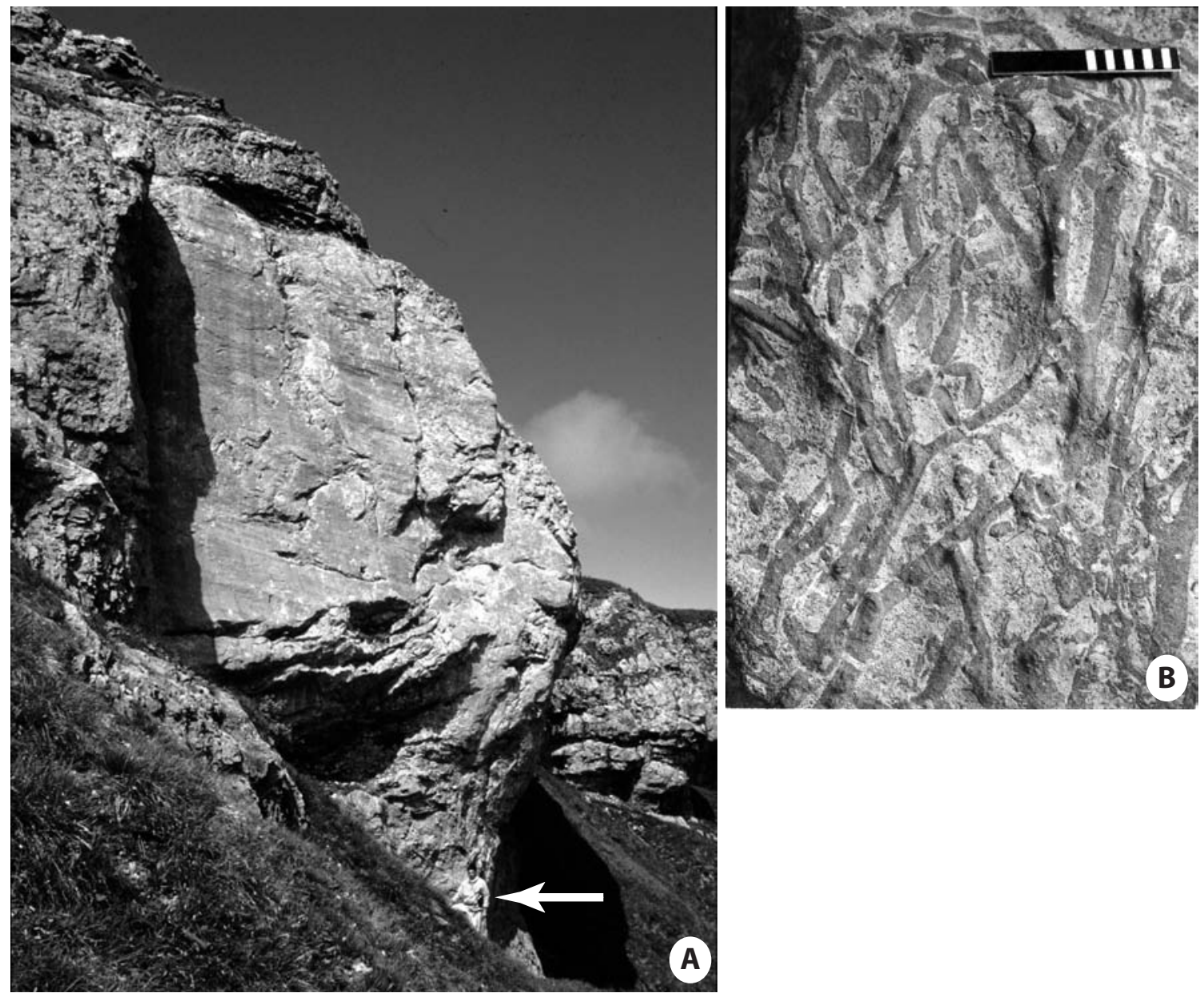

FIg. 12.-Anthracoporella mounds. A) Thick (22 m), massive Anthracoporella mound. Arrow indicates person for scale. B) The large thalli of Anthracoporella are commonly upright in growth position and show little brecciation. Marks on the scale bar are in centimeters. 

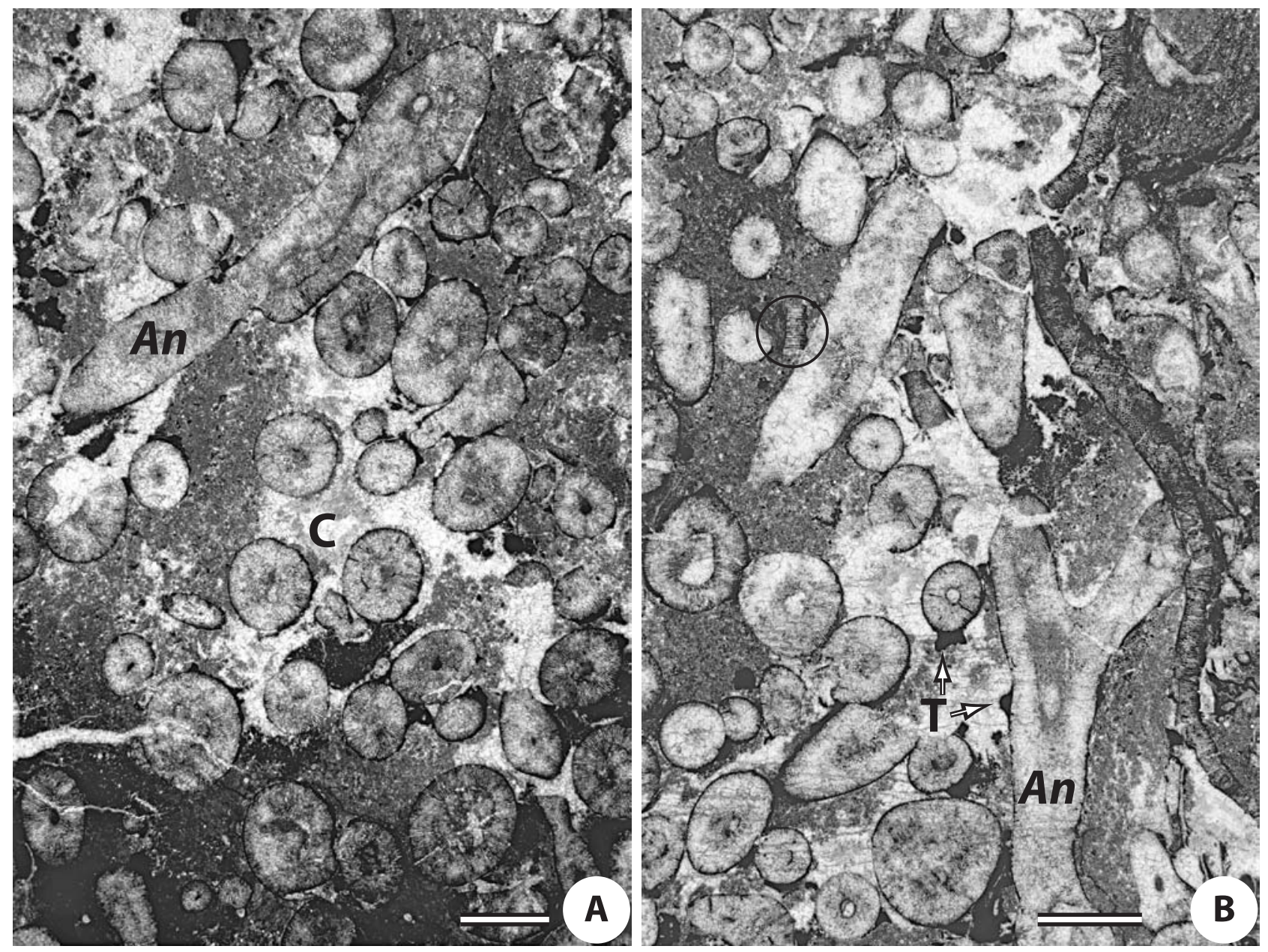

Fig. 13.-A, B) Anthracoporella boundstone. Well-preserved Anthracoporella thalli (An), obviously in growth position, enclosing framework pores filled with peloidal clotted micrite and cement (C). The rare fossil occurring in the matrix is Shamovella (T, arrows). Fragments of algal thallus (circled) are rare. Scale bar is $2.5 \mathrm{~mm}$ long for A and B.

thalli that are filled with carbonate mud, peloidal grains, synsedimentary marine cements, and micritic crusts (Fig. 13). Fossils that rarely occur in cavities are: coralline sponges, brachiopods, serpulids, and gastropods.

Intermound areas, usually one-third as thick as the mounds, consist of wackestone and packstone containing a different biota, one in which Anthracoporella is scarce, making it easy to differentiate mound facies from intermound facies.

\section{Depositional Environment and Comparisons.-}

Anthracoporella mounds grew in a low-energy environment, below wave base, as indicated by the delicate framebuilding growth forms and significant volumes of clotted peloids and micrite. The alga grew during rising sea level but "gave up" when the sea floor was below the lower limit of the photic zone. The subsequent drowning is recorded in the "Shroud Facies" that overlies Anthracoporella mounds (Samankassou, 1999).

The dasyclad alga Anthracoporella is widely reported from upper Paleozoic shallow-marine carbonates (Mamet et al., 1987; Mamet, 1991). Nevertheless, to date, actual mounds constructed by this alga are known only from the Carnic Alps (Flügel, 1987; Krainer, 1995; Samankassou, 1997, 1998).

\section{Mounds of Complex Fossil Associations}

Buildups of complex fossil associations occur in the Upper Pseudoschwagerina Limestone, at locality 14 (Fig. 1). They cannot be clearly delineated, nor can they be differentiated in the field using their fossil content (Fig. 14). They are therefore treated as a whole in the following section, and differentiation is based on thin-section petrology.

\section{Description.-}

Banks and biostromes are the common structures in the Upper Pseudoschwagerina Limestone. They are irregularly bedded, $1-3 \mathrm{~m}$ thick, and several tens of meters in lateral extent (Fig. 14). Using fossil content, as observed in thin sections, three different types of buildups have been distinguished: (1) Archaeolithophyllum-Shamovella-bryozoan (Fig. 15); (2) Archaeolithophyllum-calcisponge (Fig. 16); and (3) calcispongeShamovella (Fig. 17). The only recognizable calcisponge is Peronidella, and both Archaeolithophyllum lamellosum Wray 1964 and Shamovella built crusts (Fig. 15). A. lamellosum built structures with synoptic relief (Fig. 16), and Shamovella and bryozoans commonly encrusted the algal thalli. Peloidal-dominated 


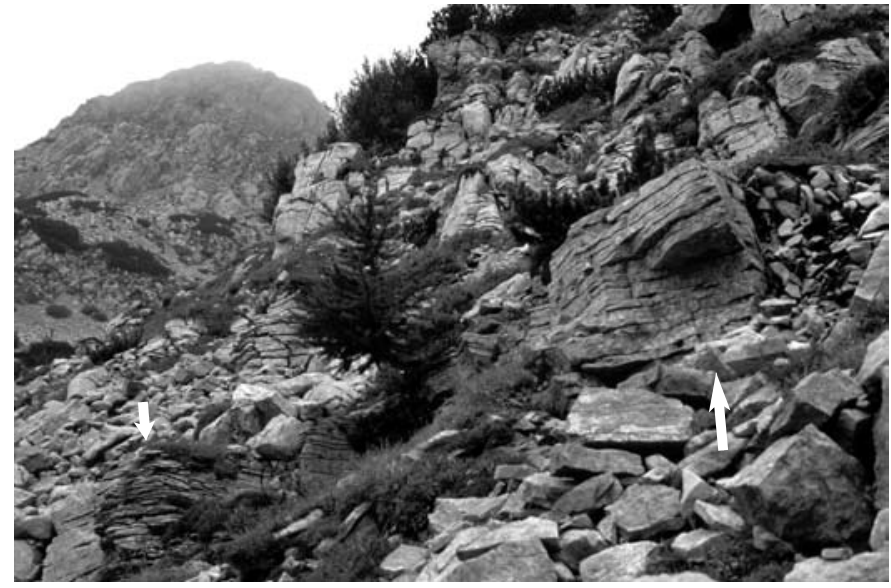

FIG. 14.-Upper Pseudoschwagerina buildups as seen at locality 14, Fig. 1. Poorly bedded banks composed of complex biotic associations (see Figs. 15-17). Note thinning of the bank toward left and dip to the left (arrows).

areas, strikingly lacking bioclasts, are volumetrically important. The mostly pendant micritic cements are volumetrically important in the calcisponge-Shamovella buildups (Fig. 17). Paleosols cap most (three-quarters) of these buildups (Samankassou, 1997). Although framework structures are common and lateral changes in thickness are obvious (Fig. 14), no high-relief, small-scale biohermal features can be delineated in the field.

\section{Depositional Environment and Comparisons.-}

The microfacies of the mounds (boundstone of delicate fragile fossils, micrite, and pendant micritic cements in and outside of cavities; Fig. 17) indicate low-energy conditions. Mounds were exposed into shallow-water environments, as

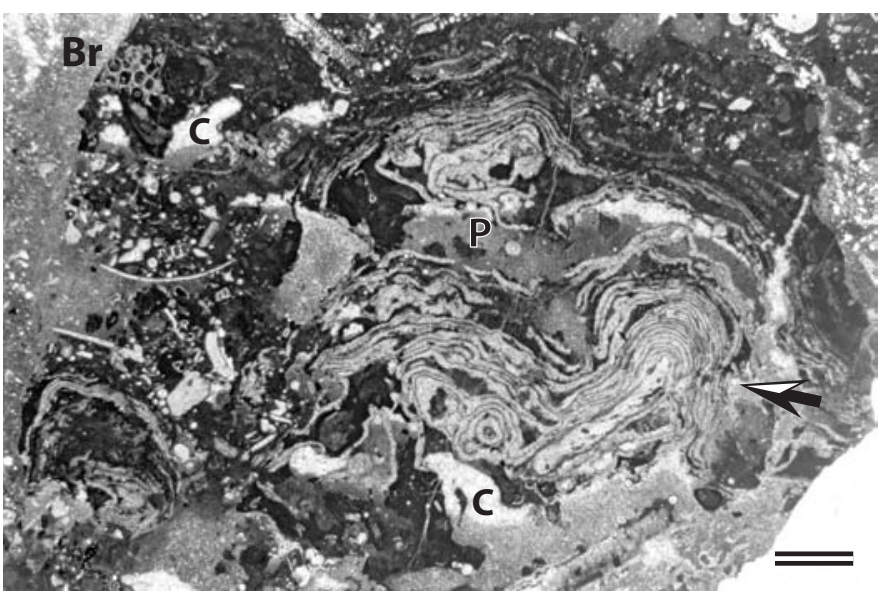

FIG. 15.-Archaeolithophyllum-Shamovella-bryozoan boundstone. Archaeolithophyllum lamellosum built thick crusts, which enclose cavities $(\mathrm{C})$ filled with peloidal micrite (P; note the irregular surfaces of infilling sediment), smaller foraminifers, and cement. Shamovella and bryozoans $(\mathrm{Br})$ commonly encrusted algal thalli. Absence of bioclasts in peloidal areas is striking, indicating low reworking. Scale bar is $1 \mathrm{~mm}$ long.

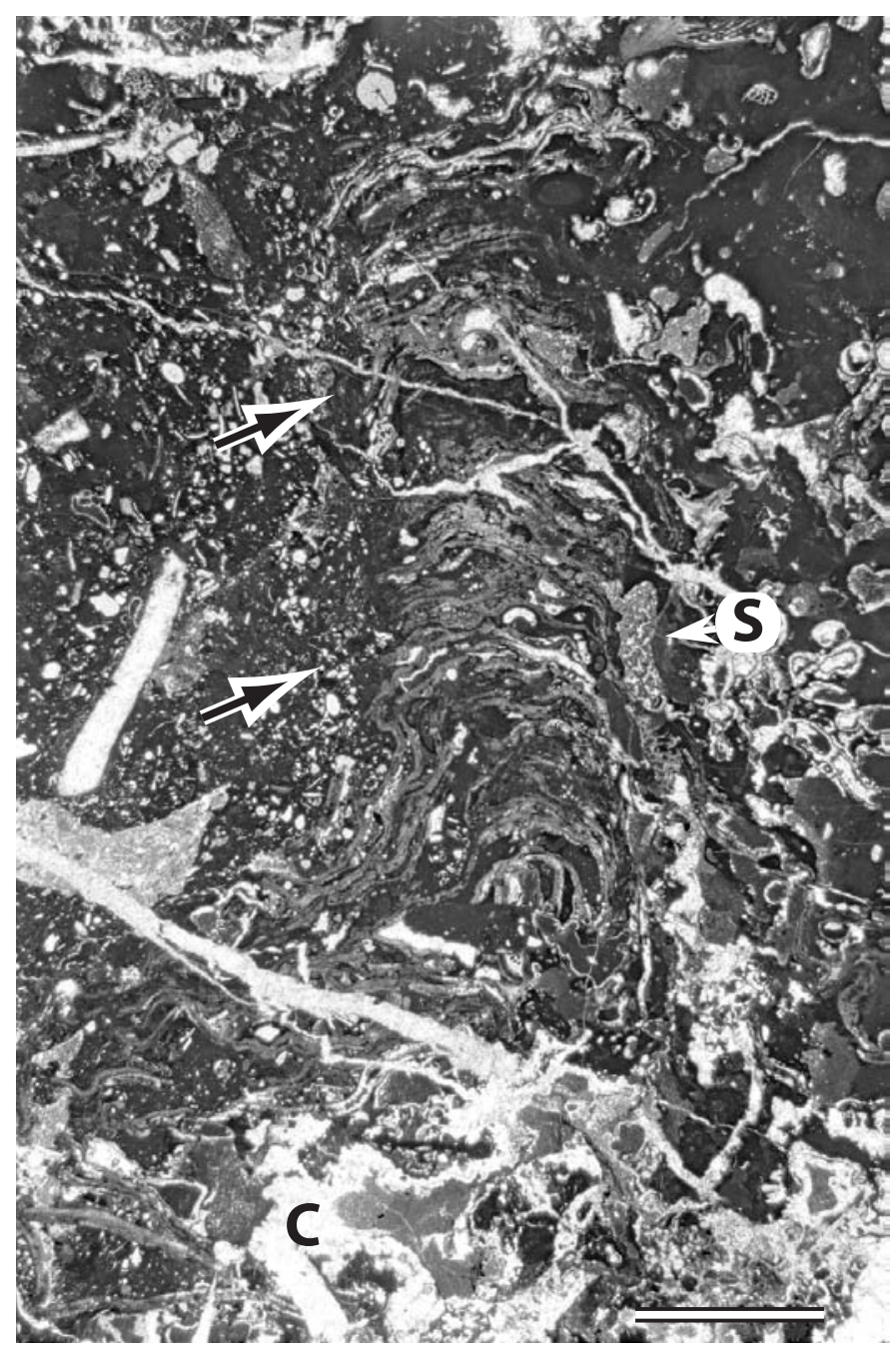

FIG. 16.-Archaeolithophyllum-calcisponge boundstone. Archaeolithophyllum lamellosum was obviously able to build millimeter-scale relief (arrows). Sponges (S) grew close to the domal forms. Micrite and cement fill cavities (C). Note irregular forms of peloidal areas that are free of bioclasts. Scale bar is $4 \mathrm{~mm}$ long.

indicated by the capping facies recording subaerial exposure (Samankassou, 1997). The microfacies and the fossil association are very similar to those of Permian buildups from the Hueco Mountains, Texas, U.S.A. (Wahlman, 1988), except for Archaeolithoporella, which is not as common in the Upper Pseudoschwagerina Limestone. The occurrence of a capping facies fits with most previous algal-mound models (Wilson, 1975, and subsequent workers), but the shallowing-upward trend of the latter is lacking in the Upper Pseudoschwagerina Limestone buildups.

\section{TRENDS IN DISTRIBUTION AND EVOLUTION OF BUILDUPS IN THE CARNIC ALPS \\ Auernig Group}

The Auernig Group records a wide spectrum of buildups (Fig. 18): 

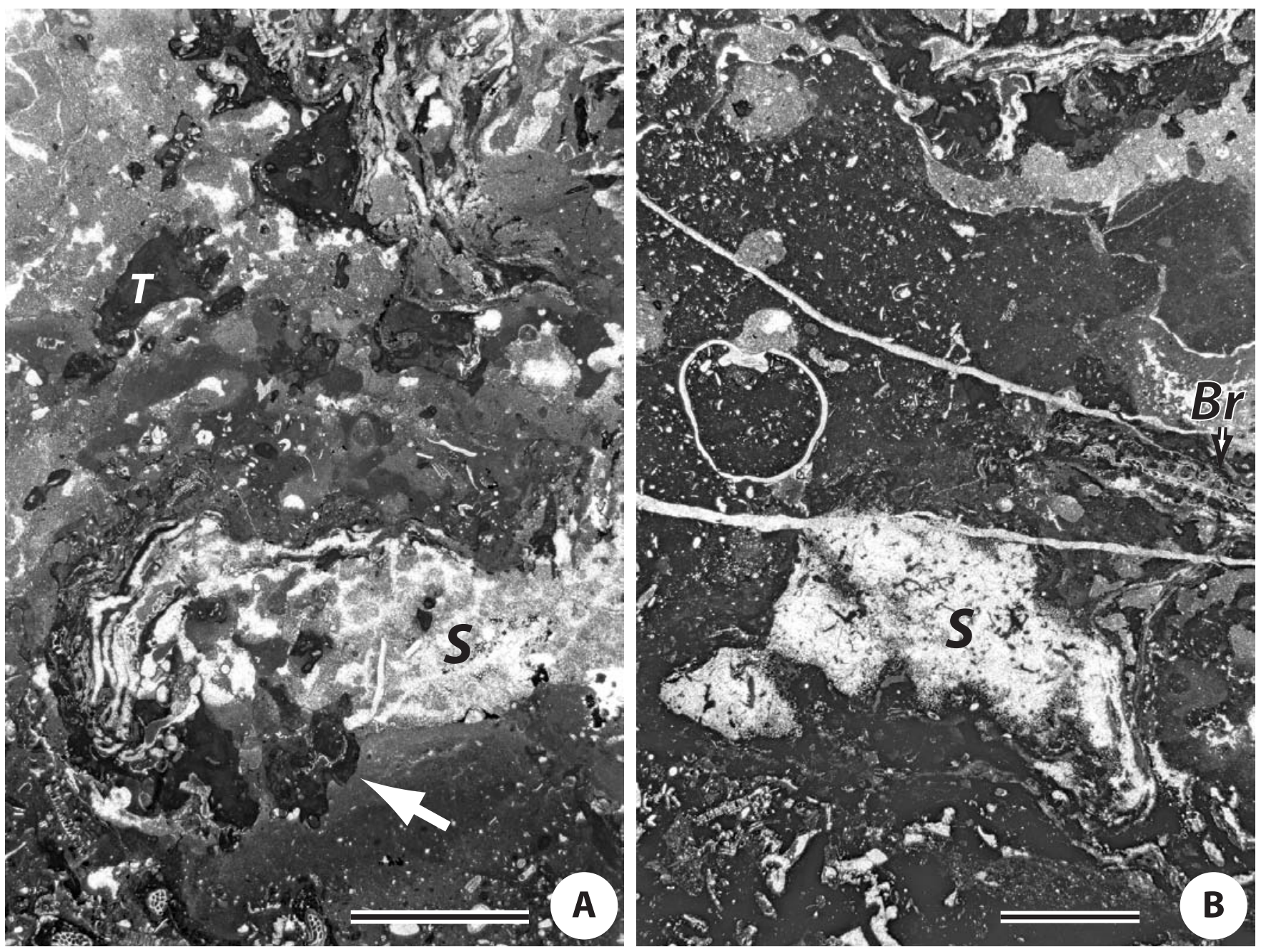

FIG. 17.-A, B) Calcisponge-Shamovella boundstone. The only recognizable calcisponge is Peronidella (S). The abundant Shamovella (T) built crusts. Micritic, generally pendant cements (arrow in A) are common and volumetrically important. Archaeolithophyllum is present but is less important compared to Figure 16. Peloidal-dominated areas are, however, volumetrically more important. Bryozoans $(\mathrm{Br}$ in $\mathrm{B})$ are rare. Scale bar is $5 \mathrm{~mm}$ long in $\mathrm{A}$ and $\mathrm{B}$.

1. Auloporid corals and the alga Rectangulina were the dominant mound builders during the early Kasimovian. These two types of buildups are limited to the basal part of the Auernig Group and to the Carnic Alps generally.

2. Algae were the dominant mound builders during late Kasimovian and early Gzhelian. Mounds generally exhibit a higher diversity than do those from the early Kasimovian. Except for phylloid algal mounds, all buildups comprise two or more fossil groups. Commonly, Archaeolithophyllum-bryozoan-brachiopod mounds are smaller (centimeter-scale) than mounds dominated by Anthracoporella-Archaeolithophyllum (meter-scale).

3. The depositional environment was carbonate-siliciclastic dominated, under moderate water depth at or just below wave base (Fig. 19A). Cooler-water fossil associations consisting of bryozoans, brachiopods, and crinoids occur in rocks just above the mounds. Thus, input of cool water is assumed to be the limiting factor of mound growth (Fig. 19A, B).
Biodiversity is high despite limiting factors such as siliciclastic input and cooler temperatures.

\section{Rattendorf Group}

\section{Lower Pseudoschwagerina Limestone.-}

Both types distinguished in the Lower Pseudoschwagerina Limestone, Anthracoporella and phylloid algal mounds, are nearly monospecific. The thickest mounds of the entire interval analyzed occur herein (Fig. 12A). The depositional environment was typically carbonate dominated, and water depths were deeper than that of mounds in the Auernig Group. Warm-water conditions are inferred for the Lower Pseudoschwagerina Limestone on the basis of the abundance of ooids and aggregates (Samankassou, 1997).

Mounds occur in the transgressive phase of Lower Pseudoschwagerina Limestone cyclothems (Samankassou, 1997). Thick mounds, resulting from increased accommodation space, indicate that mounds kept pace with sea level. Mound growth 


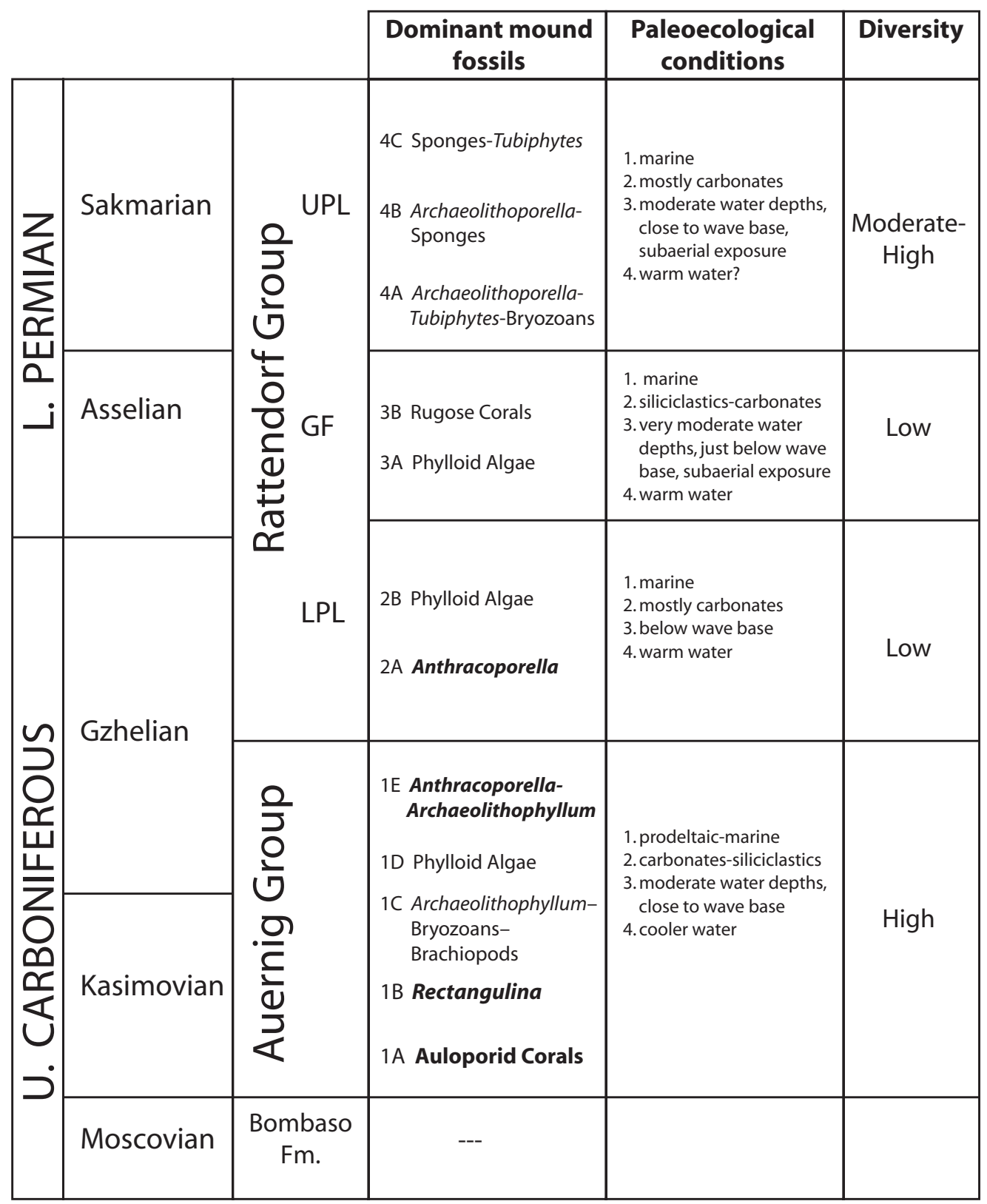

FIG. 18.-Distribution of mound types within the stratigraphic scheme of the Carnic Alps, and distinctions based on fossil associations and influencing factors. The biotic diversity is higher in the Auernig Group (siliciclastic-dominated and cool water) and moderate to high in the Upper Pseudoschwagerina Limestone (very shallow, warm? water). Diversity is low in the Lower Pseudoschagerina Limestone (deeper, carbonate dominated, warm conditions) and Grenzland Formation (very shallow, siliciclastic dominated, warm water). Boldface type indicates mound types known only from the Carnic Alps to date. LPL = Lower Pseudoschwagerina Limestone; GF = Grenzland Formation; UPL = Upper Pseudoschwagerina Limestone.

was terminated by drowning through sea-level rise ("Shroud Facies" draping Anthracoporella mounds; Samankassou, 1999)(Figs. 18, 19A, B).

\section{Grenzland Formation.-}

The two mound types encountered in the Grenzland Formation are of low diversity, and were constructed by phylloid algae and rugose corals (Fig. 18). A very shallow, siliciclastic-dominated depositional environment is inferred. The broken fossils and the presence of ooids may indicate shallow-water conditions, above wave base. Intervals of subaerial exposure evidenced by breccia, collapse, and fractures are recorded at the tops of the mounds (Fig. 19A, B). Warm-water conditions are inferred (Fig. 18).

\section{Upper Pseudoschwagerina Limestone.-}

Upper Pseudoschwagerina Limestone mounds have more diverse fossil associations than those of the Grenzland Formation 
growth position of mounds
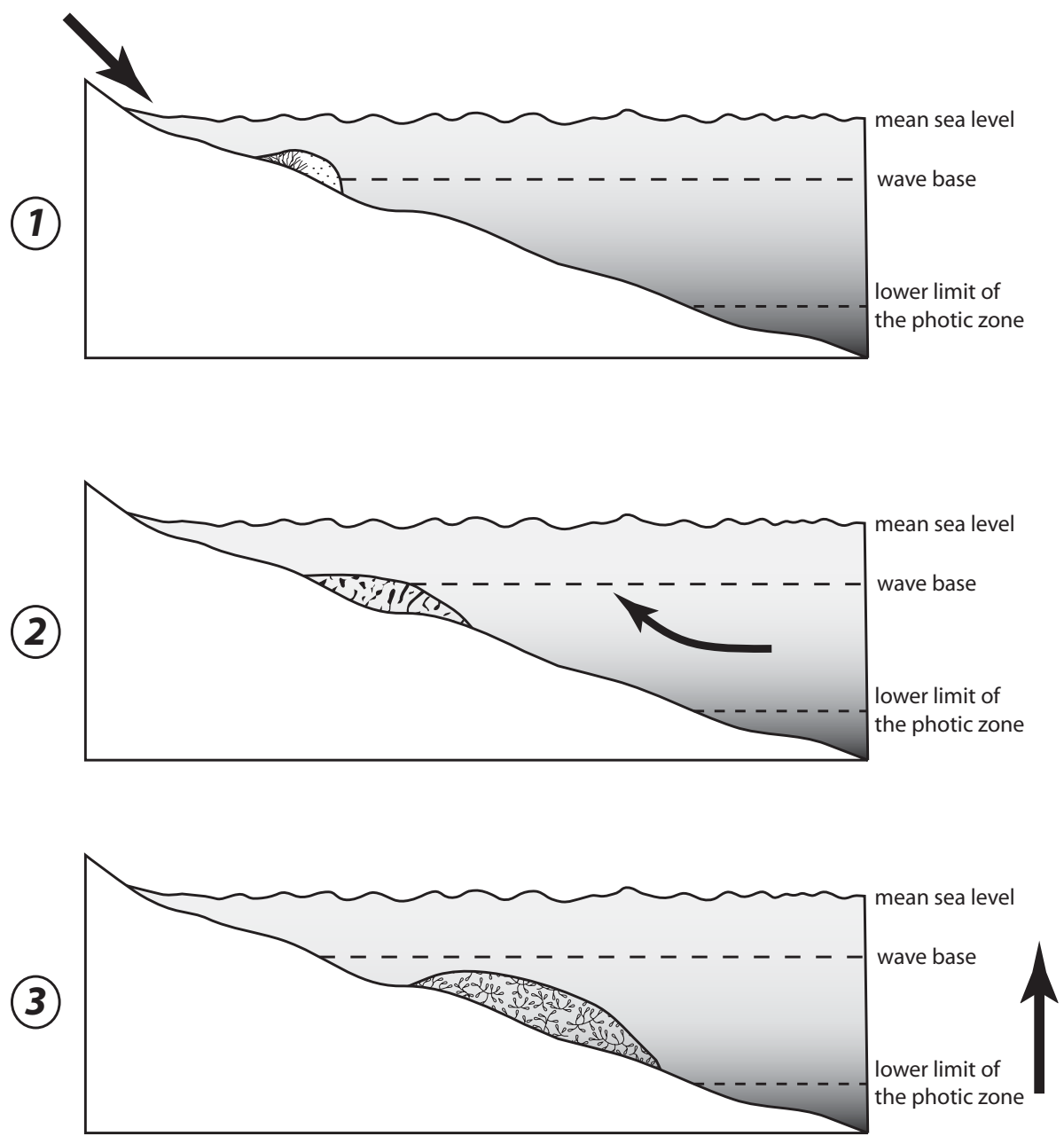

termination of mound growth

\section{input of \\ siliciclastics}

cool water

drowning

subaerial

exposure

(4)

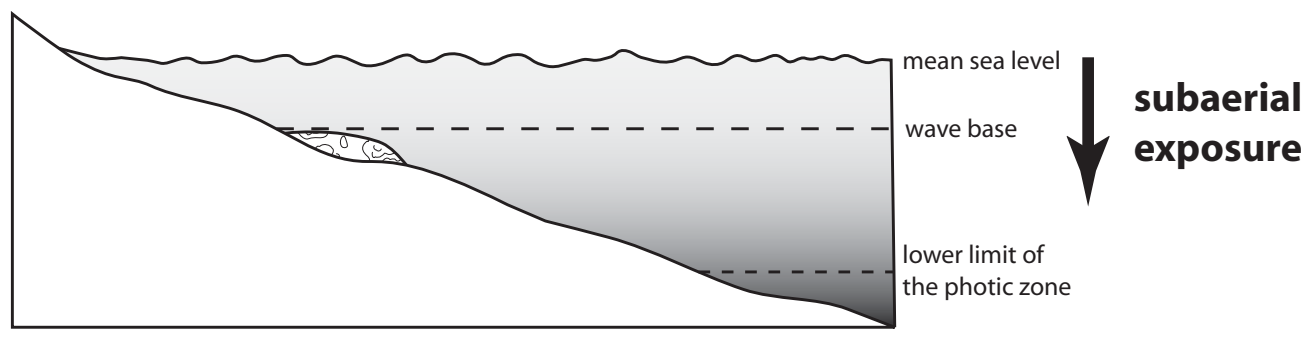

FIG. 19.-A) Depositional environment of the mounds studied and the main factors controlling their growth. (1) Coral and alga Rectangulina mounds grew in a siliciclastic-dominated environment, close to wave base. Mounds grew during phases of reduced siliciclastic input (Flügel and Krainer, 1992). Their growth was arrested by increased input of siliciclastics. (2) Algal mounds of the Auernig Group grew close to and just below wave base. Input of cool water is assumed to be the limiting factor of mound growth (Samankassou, 2002). (3) Alga Anthracoporella mounds grew during rising sea level. Before final drowning, mounds kept pace with sea level. Thicker mounds are the result of increased accommodation space. Deep-water deposits cover mounds (Samankassou, 1999). (4) Phylloid algal mounds (e.g., Grenzland Formation) grew just below wave base. Sea-level falls caused subaerial exposures of mounds. Thinner mounds are the result of decreased accommodation space. Sketches are not to scale. The difference in mound sizes reflects differences in thickness. 


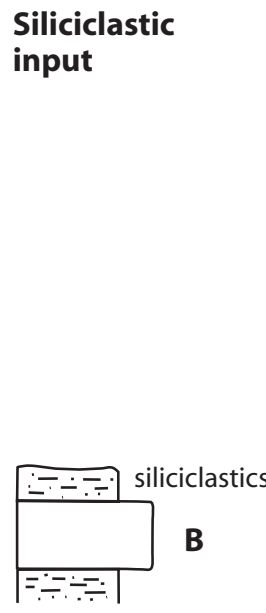

1
Cool-water

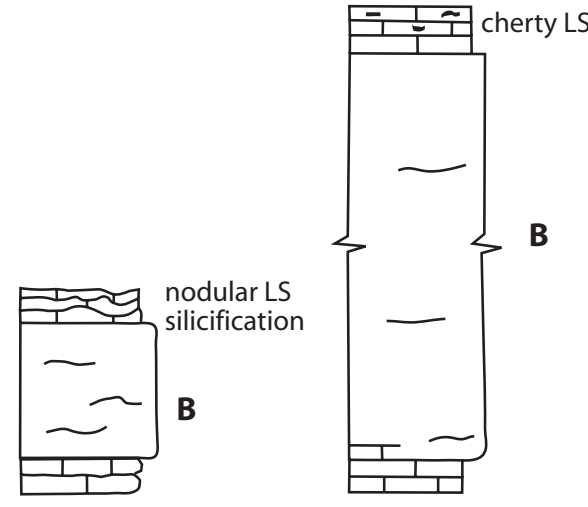

2

3

\section{Drowning Subaerial exposure \\ (Sea-level rise) (Sea-level fall)}

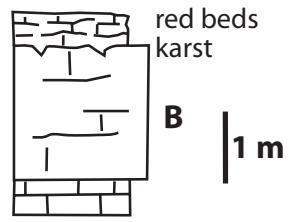

FIG. 19 (continued).-B) The growth of buildups (B) is arrested by siliciclastic input (\#1, coral and alga Rectangulina mounds, Auernig Group), cooler temperature (\#2, algal mounds of the Auernig Group), sea-level rise (\#3, drowning in the Lower Pseudoschwagerina Limestone), or sea-level fall (\#4, subaerial exposed tops of buildups in Grenzland Formation and Upper Pseudoschwagerina Limestone).

and grew in moderate water depth, below wave base (Figs. 18, 19A). Subaerial exposure horizons are common at the tops of the buildups, recording sea-level falls below actual sea floor or mound accretion to the sea surface (Fig. 19A, B). The latter seems unrealistic, inasmuch as mounds lack a shallowing-upward trend in vertical facies evolution. Furthermore, subaerial exposure directly atop subtidal mound facies implies a rapid sea-level fall.

Using the early Permian fossil associations from the Midcontinent North America (Toomey and Cys, 1979; Wahlman, 1988 , 2000) for comparison, warm-water conditions can be inferred. The higher diversity may be explained by the general trend of increasing biodiversity from the latest Carboniferous to the early Permian (Wahlman, 2000).

\section{Summary.-}

Biodiversity is highest in carbonate-siliciclastic environments and moderate water depths close to wave base. Surprisingly, the higher-diversity mounds, which were influenced by cool water, occur in the Auernig Group (Figs. 18, 19A). Inasmuch as biodiversity is supposed to be lower in cool-water settings, these results do not fit previous models. The thickest mounds occur in intervals of highest accommodation space (Lower Pseudoschwagerina Limestone), where the principal mound constructor was the dasyclad alga Anthracoporella (Samankassou, 1997, 1998). Mounds of the algae Rectangulina and Anthracoporella and mounds of auloporid corals are known only from the Carnic Alps (Table 1 ). The reason for this limitation is not clear; more studies are needed to evaluate the full geographic extent of these mounds.

No evidence of vertical zonation during mound growth was observed. Vertical changes in sediments and fossils mirror extrinsic controls, specifically changes in water temperature, sea-level fluctuations, and siliciclastic input (Fig. 19A, B; Table 1), rather than reflecting ecological succession. These unstable physical factors, which imply unstable ecological parameters, may partly explain the dimensions of the mounds, the domination of buildups by opportunistic biota (mainly algae), and the overall low biodiversity of buildups.

\section{COMPARISONS WITH CONTEMPORANEOUS AREAS}

Most of the reported contemporaneous carbonate buildups occur in the Carnic Alps (Table 1). Mounds of the algae Rectangulina and Anthracoporella and mounds of auloporid corals are so far known only from the Carnic Alps. The occurrence of Archaeolithophyllum and Anthracoporella in the same mound is unique to the Carnic Alps, as well. Two major mound types are seemingly absent in the Carnic Alps: chaetetid sponge mounds and Palaeoaplysina (fossil of uncertain systematic position) mounds (Table 1). Palaeoaplysina is common in higher-latitude settings. Donezella algal mounds generally occur in older rocks (Mamet, 1991; Watkins, 1999; Samankassou, 2001), and bryozoan mounds are more common in Artinskian and younger rocks (Beauchamp, 1992).

According to most of the previous models, mounds grew during falling sea level (cf. Soreghan and Giles, 1999a, for a critical discussion). In the Carnic Alps, however, mound growth occurred at various positions on the shelf (Fig. 19B), and the mound thickness varies accordingly. As demonstrated in the Orogrande Basin, New Mexico, U.S.A., multiple factors can potentially affect mound growth and thickness (Soreghan and Giles, 1999a, 1999b).

\section{CONCLUSIONS}

The buildups described range from a few centimeters to several meters in thickness. Mound rocks are massive (particularly those dominated by Anthracoporella) to indistinctly bedded (Archaeolithophyllum-bryozoan dominated). Mound intervals consist of boundstone, mostly with a peloidal-clotted texture. Intermound areas consist of a bioclastic wackestone, typically biodiverse, with fusulinaceans and the alga Epimastopora, which commonly occur with gastropods, ostracodes, and smaller foraminifers. Fossils within the mounds differ from those in the intermound and off-mound areas. Sedimentary structures, particularly large-scale cross-bedding in beds underlying the mounds, 
TABLE 1.-Occurrence and distribution of buildup types in the Carnic Alps versus other settings.

\begin{tabular}{|l|c|c|c|}
\hline \multicolumn{1}{|c|}{ BUILDUP TYPES } & \multicolumn{2}{c|}{$\begin{array}{c}\text { CARNIC ALPS } \\
\text { (AUSTRIA-ITALY) }\end{array}$} & $\begin{array}{c}\text { CONTEMPORANEOUS } \\
\text { SETTINGS }\end{array}$ \\
\hline & Auernig Group & Rattendorf Group & \\
\hline Auloporid coral & $\mathrm{X}$ & & $\mathrm{X}$ \\
\hline Rugose coral & $\mathrm{X}$ & & $\mathrm{X}$ \\
\hline Rectangulina & $\mathrm{X}$ & $\mathrm{X}$ & $\mathrm{X}$ \\
\hline Archaeolithophyllum-Anthracoporella & $\mathrm{X}$ & $\mathrm{X}$ & $\mathrm{X}$ \\
\hline Phylloid algal & $\mathrm{X}$ & $\mathrm{X}$ & $\mathrm{X}$ \\
\hline Anthracoporella & & $\mathrm{X}$ & $\mathrm{X}$ \\
\hline Archaeolithophyllum-Bryozoan-Tubiphytes & & & $\mathrm{X}$ \\
\hline Archaeolithophyllum-Calcisponges & & & \\
\hline Sponge-Tubiphytes & & & \\
\hline Chaetetid sponges & & & \\
\hline Palaeoaplysina & & & \\
\hline
\end{tabular}

Donezella algal mounds generally occur in older rocks (Mamet, 1991; Watkins, 1999; Samankassou, 2001), and bryozoan mounds are more common in Artinskian and younger rocks (Beauchamp, 1992); both are therefore not considered in this diagram. For references, see Young and Rush (1956), Wilson (1975), Fagerstrom (1987), West (1988), Wahlman (1988, 2000), and other authors cited in the text.

indicate deposition close to wave base, whereas mounds grew below wave base. Cool-water fossil assemblages at the tops of most Auernig mounds indicate a possible influence of water temperature that may have been responsible for the termination of mound growth. Sea-level fluctuations were probably a more important control on Rattendorf mounds, as indicated by intervals of drowning (Anthracoporella mounds, Lower Pseudoschwagerina Limestone) and subaerial exposure of mounds (Grenzland Formation, Upper Pseudoschwagerina Limestone).

Whereas most carbonate buildup types reported from contemporaneous areas so far occur in the Carnic Alps, buildups of the algae Anthracoporella and Rectangulina and buildups of auloporid corals are not reported from other settings.

\section{ACKNOWLEDGMENTS}

Support and fieldwork assistance of the actual Pangea Working Group in Erlangen (E. Flügel, B. Fohrer, H. Forke) is gratefully acknowledged. Information provided by B. Beauchamp (Calgary, Canada) and Greg Wahlman (Houston, TX, U.S.A.), and review of an earlier version of the manuscript by Robert Riding (Cardiff, U.K.) are very much appreciated. The referees Bill Morgan, Lynn Soreghan, and Ron West thankfully made thorough constructive improvements to the submitted manuscript. John Southard and Bob Clarke are gratefully acknowledged for their editorial suggestions, which greatly improved the final manuscript. The financial support of the German Research Foundation (DFG, Bonn, Germany), Project FL 42/72, is thankfully acknowledged. I benefited from a grant from the Swiss National Science Foundation (Project No. 20-56491.99) during the final draft of the manuscript.

\section{REFERENCES}

Beauchamp, B., 1992, Carboniferous and Permian reefs of Sverdrup Basin, Canadian Arctic: an aid to Barents Sea exploration, in Vorren, T.O., Bergsager, E., Dahl-Stammes, Ø.A., Holter, E., Johansen, B., Lie, E., and Lund, T.B., eds., Arctic Geology and Petroleum Potential: Norwegian Petroleum Society, Special Publication 2, p. 217-241.
BoeCKelMANN, K., 1985, Mikrofazies der Auernig-Schichten und GrenzlandBänke westlich des Rudnig Sattels (Karbon-Perm: Karnische Alpen): Facies, v. 13, p. 155-174.

Dawson, W.C., and CarozzI, A.V., 1986, Anatomy of a phylloid algal buildup, Raytown Limestone, Iola Formation, Pennsylvanian, southeast Kansas, U.S.A.: Sedimentary Geology, v. 47, p. 221-261.

Fagerstrom, J.A., 1987, The Evolution of Reef Communities: New York, John Wiley \& Sons, $592 \mathrm{p}$.

Feldman, H.R., AND MaPles, C.G., 1989, Sedimentological implications of encrusting organisms from the phylloid algal mound of the Sniabar Limestone near Unionstown Kansas, in Watney, W.L., French, J.A., and Ranseen, E.K., Sequence Stratigraphic Interpretations and Modeling of Cyclothems: Kansas Geological Society, 41st Annual Field Trip, Guidebook, p. 173-178.

FLÜGEL, E., 1980, Die Mikrofazies der Kalke in den Trogkofel-Schichten der Karnischen Alpen: Carinthia II, Sonderheft, v. 36, p. 51-100.

FLÜGEL, E., 1981, Lower Permian Tubiphytes / Archaeolithoporella buildups in the southern Alps (Austria and Italy), in Toomey, D.F., ed., European Fossil Reef Models: Society of Economic Paleontologists and Mineralogists, Special Publication 30, p. 143-160.

FLÜGEL, E., 1987, Reef Mound-Entstehung: Algen-Mounds im Unterperm der Karnischen Alpen: Facies, v. 17, p. 73-90.

FLÜGEL, E., AND KRAINER, K., 1992, Allogenic and autogenic controls of reef mound formation: Late Carboniferous auloporid coral buildups from the Carnic Alps, Italy: Neues Jahrbuch für Geologie und Paläontologie, Abhandlungen, v. 185, p. 39-62.

Flügel, E., Fohrer, B., Forke, H., Krainer, K., and SamanKassou, E., 1997, Cyclic sediments and algal mounds in the upper Paleozoic of the Carnic Alps: field trip, International Association of Sedimentologists, 18th IAS Regional European Meeting of Sedimentology, Heidelberg, September 2-4, 1997, guidebook: Gaea Heidelbergensis, v. 4, p. 79-100.

FoRKE, H.C., AND SAMANKASSOU, E., 2000, Biostratigraphical correlation of Late Carboniferous (Kasimovian) sections in the Carnic Alps (Austria/Italy): Integrated paleontological data, facies, and discussion: Facies, v. 42, p. 171-204.

Frost, J.G., 1975, Winterset algal-bank complex, Pennsylvanian, eastern Kansas: American Association of Petroleum Geologists, Bulletin, v. 59, p. 265-291.

HECKEL, P.H., 1974, Carbonate buildups in the geologic record: a review, in Laporte, L.F., ed., Reefs in Time and Space: Society of Economic 
Paleontologists and Mineralogists, Special Publication 18, p. 90154.

Heckel, P.H., And Cocke, J.M., 1969, Phylloid algal-mound complexes in outcropping Upper Pennsylvanian rocks of Mid-Continent: American Association of Petroleum Geologists, Bulletin, v. 53, p. 1058-1074.

Hill, D., 1939, A monograph of the Carboniferous rugose corals of Scotland, Part I: Palaeontographical Society, London, p. 1-78.

Homann, W., 1969, Fazielle Gliederung der Unteren Pseudoschwagerinenkalke (Unter-Perm) der Karnischen Alpen: Neues Jahrbuch für Geologie und Paläontologie, Monatshefte, v. 1969, p. 265-280.

KAHLER, F., 1955, Entwicklungsräume und Wanderwege der Fusulinen im Euroasiatischen Kontinent: Geologie, v. 4, p. 179-188.

KonISHI, K., AND WraY, J.L., 1961, Eugonophyllum, a new Pennsylvanian and Permian algal genus: Journal of Paleontology, v. 35, p. 659-666.

KRAINER, K., 1992, Fazies, Sedimentationsprozesse und Paläogeographie im Karbon der Ost-und Südalpen:Vienna, Geologische Bundesanstalt, Jahrbuch, v. 135, p. 99-193.

Krainer, K., 1995, Anthracoporella mounds in the Late Carboniferous Auernig Group, Carnic Alps (Austria): Facies, v. 32, p. 195-214.

LAPORTE, L.F., 1962, Paleoecology of the Cottonwood Limestone (Permian) northern Mid-continent: Geological Society of America, Bulletin, v. 73 , p. 521-541.

LINEHAN, J.M., AND SutTERLIN, P.G., 1986, Factors influencing production in the Toronto Limestone (Shawnee Group, Upper Pennsylvanian), Snake Creek field, Clark County, Kansas: Carbonates and Evaporites, v. 1, p. 44-60.

MAmet, B., 1991, Carboniferous calcareous algae, in Riding, R., ed., Calcareous Algae and Stromatolites: Berlin, Springer, p. 370-451.

MAMET, B.L., Roux, A., AND NAssichuK, W.W., 1987, Algues Carbonifères et Permiennes de l'Arctique Canadien: Geological Survey of Canada, Bulletin 342, p. 1-143.

Pray, L.C., And WraY, J.L., 1963, Porous algal facies (Pennsylvanian) Honaker Trail, San Juan Canyon, Utah, in Bass, R.O., and Sharps, S.L., eds., Shelf Carbonates, Paradox Basin (4th Field Conference Guidebook): Durango, Colorado, Four Corners Geological Society, p. 273.

RiDING, R., 1993, Shamovella obscura: the correct name for Tubiphytes obscurus (fossil): Taxon, v. 42, p. 71-73.

SAMANKASsou, E., 1997, Muster und Kontrolle der zyklischen Sedimentation im Jungpaläozoikum (Oberkarbon-Unterperm) der Karnischen Alpen, Österreich: eine integrierte Untersuchung: Unpublished Ph.D. Dissertation, University of Erlangen-Nürnberg, Germany, 397 p.

SAMANKASSOU, E., 1998, Skeletal framework mounds of dasycladalean alga Anthracoporella, Upper Paleozoic, Carnic Alps, Austria: Palaios, v. 13, p. 297-300.

SAMANKASSOU, E., 1999, Drowning of algal mounds: Records from the Lower Pseudoschwagerina Limestone, Upper Carboniferous, Carnic Alps, Austria: Sedimentary Geology, v. 127, p. 209-220.

SAMANKASSOU, E., 2001, Internal structure and depositional environment of Late Carboniferous mounds from the San Emiliano Formation, Cármenes Syncline, Cantabrian Mountains, Northern Spain: Sedimentary Geology, v. 145, p. 235-252.

SAMANKASSOU, E., 2002, Cool-water carbonates in a paleoequatorial shallow-water environment: The paradox of the Auernig cyclic sediments (Upper Pennsylvanian, Carnic Alps, Austria-Italy) and its implications: Geology, v. 30, p. 655-658.

SAMANKASSOU, E., AND WEST, R.R., 2000, Construction versus accumulation in phylloid algal mounds: Case study from the Pennsylvanian Frisbie Limestone Member, Kansas, U.S.A. (abstract): SEPM-IAS Research Conference "Permo-Carboniferous Carbonate Platforms and Reefs", p. 121.

SAMANKASSOU, E., AND WEST, R.R., 2002, Construction versus accumulation in phylloid algal mounds: an example of a small constructed mound in the Pennsylvanian of Kansas, U.S.A.: Palaeogeography, Palaeoclimatology, Palaeoecology, v. 185, p. 379-89.
SOREGHAN, G.S., AND GILES, K.A., 1999a, Facies character and stratal responses to accommodation in Pennsylvanian bioherms, western Orogrande Basin, New Mexico: Journal of Sedimentary Research, v. 69, p. 893-908.

SOREGHAN, G.S., AND GILES, K.A., 1999b, Amplitudes of Late Pennsylvanian glacioeustasy: Geology, v. 27, p. 255-258.

TedesCo, L.P., AND WANLESS, H.R., 1989, The depositional sequence of phylloid mounds; a reappraisal (abstract): Geological Society of America, Abstracts with Programs, v. 21, p. 292.

TEDEsCO, L.P., AND WANLESS, H.R., 1995, Growth and burrow-transformation of carbonate banks: comparison of modern skeletal banks of South Florida and Pennsylvanian phylloid banks of south-eastern Kansas, U.S.A., in Monty, C.L.V., Bosence, D.W.J., Bridges, P.H., and Pratt, B.R., eds., Carbonate Mud-Mounds; Their Origin and Evolution: International Association of Sedimentologists, Special Publication 23, p. 495-521.

ToOMEY, D.F., 1976, Paleosynecology of a Permian plant dominated marine community: Neues Jahrbuch für Geologie und Paläontologie, Abhandlungen, v. 152, p. 1-18.

ToomeY, D.F., 1991, Late Pennsylvanian phylloid-algal bioherms, Orogrande basin, south-central New Mexico and Texas, in Barker, J.M., Kues, B.S., Austin, G.S., and Lucas, S.G., eds., Geology of the Sierra Blanca, Sacramento and Capitan Ranges, New Mexico: New Mexico Geological Society, 42nd Annual Field Conference, Guidebook, p. 213-220.

Toomey, D.F., AND BABCOCK, J.A., 1983, Precambrian and Paleozoic algal carbonates, west Texas-southern New Mexico: Golden, Colorado, Colorado School of Mines, Professional Contributions, v. 11, 345 p.

ToOMEY, D.F., AND CYS, J.M., 1979, Community succession in small bioherms of algae and sponges in the Lower Permian of New Mexico: Lethaia, v. 12 , p. $65-74$.

ToOmeY, D.F., Wilson, J.L., and ReZAK, R., 1977, Evolution of Yucca Mound complex, Late Pennsylvanian phylloid algal buildup, Sacramento Mountains, New Mexico: American Association of Petroleum Geologists, Bulletin, v. 61, p. 2115-2133.

Venturini, C., 1990, Geologia delle Alpi Carniche centro orientali: Udine, Comune di Udine, Edizioni del Museo Friulao di Storia Naturale, Publicazione no. 36, 220 p.

Wahlman, G.P., 1988, Subsurface Wolfcampian (Lower Permian) shelfmargin reefs in the Permian Basin of west Texas and southeastern New Mexico, in Morgan, W.A., and Babcock, J.A., eds., Permian Rocks of the Midcontinent: SEPM, Midcontinent Section, Special Publication 1, p. 177-204.

Wahlman, G.P., 2000, Composition and distribution of Upper Pennsylvanian-Lower Permian mounds and reefs (abstract): SEPM-IAS Research Conference "Permo-Carboniferous Carbonate Platforms and Reefs", p. 145.

WARNKE, K., 1997, Microbial carbonate production in a starved basin: the crenistria limestone of the upper Visean German Kulm facies: Palaeogeography, Palaeoclimatology, Palaeoecology, v. 130, p. 209225.

WATKINS, R., 1999, Upper Paleozoic biostromes in island-arc carbonates of the eastern Klamath Terrane, California: Palaeontological Research, v. 3, p. 151-161.

WeLCH, J.R., 1977, Petrology and development of algal banks in the Millersville Limestone Member (Bond Formation, Upper Pennsylvanian) of the Illinois Basin: Journal of Sedimentary Petrology, v. 47, p. 351-365.

West, R.R., 1988, Temporal changes in Carboniferous reef mound communities: Palaios, v. 3, p. 152-169.

WiLson, E.C., 1963, The tabulate coral Multithecopora YOH from the Chaetetes-Profusulinella faunizone in eastern Nevada: Journal of Paleontology, v. 37, p. 157-163.

WiLson, J.L., 1972, Cyclic and reciprocal sedimentation in Virgilian strata of southern New Mexico, in Elam, J.G., and Chuber, S., eds., Cyclic 
Sedimentation in the Permian Basin, 2nd Edition: West Texas Geological Society, Publication 72-60, p. 82-99.

WILsON, J.L., 1975, Carbonate Facies in Geologic History: New York, Springer, $471 \mathrm{p}$

WRAY, J.L., 1964, Archaeolithophyllum, an abundant calcareous alga in limestones of the Lansing Group (Pennsylvanian), southeastern Kansas: Kansas Geological Survey, Bulletin 170, p. 1-13.

WraY, J.L., 1977, Calcareous Algae: New York, Elsevier, 185 p.

YounG, K.P., AND RusH, R.W., 1956, Shape and deposition of small Pennsylvanian bioherm, McCulloch County, Texas: American Association of Petroleum Geologists, Bulletin, v. 40, p. 1988-1994. 